\title{
The impact of corporate governance practices on R\&D efforts: a look at shareholders' rights, cross-listing, and control pyramid
}

Stephane Lhuillery*

The article considers the impact of multiple shareholder-oriented governance practices on R\&D decisions. Based on a sample of 5528 firms belonging to 110 large French listed business groups, our results substantiate the idea that shareholder-oriented governance practices and a lower position in a control pyramid are better for R\&D investment. The introduction of any additional shareholder oriented practice is found to result in more R\&D. We show, however, that this Anglo-Americanization of the French corporate governance system is only partial. We provide evidence of the co-existence of an old French system of corporate governance with a hybrid model of corporate governance. The lack of concrete results on complementarity among shareholder-oriented governance practices casts doubt on the stability of this hybrid model in the French context.

JEL classification: G34, O31, 032.

\section{Introduction}

$\mathrm{R} \& \mathrm{D}$ investment is of major importance for the introduction of new products and process technologies, driving firms to achieve better productivity and long-term profitability (Mansfield et al., 1977; Grabowski and Mueller, 1978; Hirschey, 1982; Ravenscarft and Scherer, 1982; Hanel and Saint-Pierre, 2002). One major problem, however, is that returns from R\&D investment are uncertain. Moreover, any

\footnotetext{
${ }^{\star}$ Stephane Lhuillery, ICN Business School, 3 place Edouard Branly, 57070 Metz Technopôle, France; and, Ecole Polytechnique Federale de Lausanne, College du Management de la Technologie, Station 5, Odyssea 1.18, CH-1015 Lausanne, Switzerland. e-mail: stephane.lhuillery@icn-groupe.fr
} 
investment in R\&D activities, which are by nature idiosyncratic, must be long term and requires the employment of "off-line" specialists (Dosi, 1988; Holmstrom, 1989; Nelson and Nelson, 2002), something which may impact negatively on short-term performance (Hoskisson et al., 1993).

In order to cope with these dimensions, the academic literature to date has underlined the role of size, industry and spillovers on R\&D decisions and innovative outputs. The strategic dimensions of $\mathrm{R} \& \mathrm{D}$ and innovation first became prominent when scholars focused on the following factors: appropriation strategies implemented by firms in order to deter imitation (see Levin et al., 1987); investments into absorptive capacities likely to allow companies to access and exploit external knowledge (see Cohen and Levinthal, 1990); finally, the role of R\&D cooperative agreements in order to share risks, costs, and knowledge (Cassiman and Veugelers, 2002). The huge amount of results available on these aspects provides little concrete information, however, about how decisions to invest in R\&D activities and to launch innovation are actually taken by managers (Greve, 2003). For example, the influence of governance practices implemented by shareholders, boards, committees, or stakeholders (employees, banks, government, suppliers, etc.) in order to alleviate agency costs at different levels of the firm (directors, managers, R\&D employees), and to reduce the high costs of creating, integrating and sharing knowledge (Lacetera, 2001; Foss, 2007) is usually not explored by the literature on innovation which instead focuses more on problem-solving issues (Dosi et al., 2003).

Only compensation schemes have received some attention in the literature, wherein it is assumed that managers and/or R\&D employees are likely to adopt opportunistic behaviors when the following factors exist: asymmetric information, different risk profiles, difficult, and costly to verify individual efforts and finally, idiosyncratic investments. In this setting, incentive mechanisms are practices or provisions likely to align or conciliate managers' decisions regarding $R \& D$ and innovation (see Hoskisson et al., 1993; Hitt et al., 1996) or R\&D employees' choices (see Holmstrom, 1989) with shareholders' interests. The agency-theory viewwhere the more governance practice increases the control of shareholders, the more managers will be aligned and risk takers more likely to invest in R\&D and launch innovation-remains in this respect a dominant reference.

Corporate governance practices are, however, broader and more complex than compensation schemes as various scandals in the US and in Europe (e.g. Enron, Worldcom, Credit Lyonnais, Vivendi, Ahold, Parmalat, etc.) or the recent collapse of the world banking system remind us. Hence, strategic behaviors, including R\&D and innovation, are likely to be influenced simultaneously by different governance practices. This is precisely the point raised by a strand in the corporate governance literature dealing with various control mechanisms and aiming at identifying effective corporate governance practices and corporate governance systems (e.g. Danielson and Karpoff, 1998; Gompers et al., 2003). These works are focused on the market 
value of firms and unfortunately do not address the relationship between multiple corporate governance practices and R\&D strategies. ${ }^{1}$

Based on a sample of 5528 firms belonging to the 110 largest French public listed companies, the present article is a first attempt to fill this gap. It proposes an econometric model built at the micro-firm level, aimed at accurately testing the impact of multiple shareholder-oriented governance practices on R\&D decisions. Thanks to original data, we identify 19 rated governance practices allowing us to build nine indexes measuring nine different fields through which shareholders are likely to influence managerial decisions as follows: governance policy, communication structure, communication tools, communication quality, annual meeting, voting rules, board organization, compensation schemes aligned with shareholders, as well as a lack of litigation. All are supposed to boost R\&D efforts. Despite known discrepancies (see e.g. O'Reilly and Main, 2010), we deliberately adopt the shareholder model as a benchmark in our article: it allows us to test the strengths and weaknesses of the different hypotheses underpinning it. In an original way our empirical model introduces a test of complementarity among the different corporate governance practices, without which, results for each practice could be misinterpreted. In the French context, the complementarity test also allows us to check for the existence and stability of a possible hybrid governance model, defined as a mixture of French and Anglo-American corporate governance practices.

The original model which we propose here addresses two further dimensions likely to influence R\&D and which are usually neglected or are given scant attention in the literature on governance practices: the present article controls for the possible influence on R\&D of a firm's position on the control pyramid (Doidge et al., 2007). Corporate governance practices may indeed influence top-executives working in headquarters but this influence may be diluted when managers work in a loosely controlled affiliate. Our model also controls for the influence on R\&D strategies of mainland European companies cross-listed (Morck et al., 2005) on the New York or London stock exchanges. Firms must comply with national practices but also can comply to other country governance practices especially when they want to invest, produce, or find money abroad. When French firms are listed in NYC or London, they are thus expected to adopt Anglo-American shareholder value-oriented practices.

\footnotetext{
${ }^{1}$ Following the seminal paper of Francis and Smith (1995), a third strand in the corporate governance deals with R\&D and innovation, exploring the positive role of ownership concentration on manager alignment, or the positive impact of long-term oriented block-holders (e.g. pension funds). This literature fails however to provide coherent evidence on the optimal ownership or board structure. Positive, neutral, or negative relationships are found in turn when the influences on R\&D of owner concentration (compare the results obtained by Tribo et al., 2007 to those of Czarnitzki and Kraft, 2003 or Yafeh and Yosha, 2003), or the distribution of decision-making among the different types of stakeholders (e.g. see Francis and Smith, 1995; Cescon 2002; Gugler 2003) are explored.
} 
Hence, our article poses an empirical model flexible enough to carefully explore the relevance of the shareholder model and to reinsert the corporate governance model into a broader framework where (national) institutions matter. Doing so, this article proposes an empirical framework which is likely to bridge the gap between existing literature focused on corporate governance practices (Danielson and Karpoff, 1998; Gompers et al., 2003) and the broader neo-institutionalist literature aimed at identifying and explaining the emergence, the heterogeneity and the co-evolution of the various national governance systems and their organizational, industrial, and institutional environments (La Porta et al., 1999; Hall and Soskice, 2001; Aoki, 2001, 2007; Amable, 2003; Aoki and Jackson, 2008).

The remainder of the article is organized as follows. Section 2 develops the theoretical arguments explaining the influence on R\&D decisions of the different corporate governance practices which form the foundation for the shareholder model. We survey theoretical but also empirical results which now systematically cast doubt on the influence of shareholder-oriented practices on performances; as far as possible, we also take into account the possible influence within the context of French institutions. The next section introduces the various data sources, defines the different available variables especially concerning governance provisions and specifies the econometric model. In the Section 4, descriptive statistics and econometric results are exposed in turn. The final section presents and discusses our conclusions.

\section{R\&D and corporate governance practices}

The literature on governance practices is usually articulated around four main categories borrowed from the shareholders' model: the market for corporate control, information systems, board practices, and compensation schemes. We first explore how these board practices may affect or not R\&D investment decisions of companies. We then explore additivity and complementarity among practices. Finally, we present the influence of cross-listing and the control pyramid.

\section{$2.1 R \nLeftarrow D$ decisions and the defense of shareholders' rights}

One important characteristic within a governance model is the role of the market for corporate control. Owners exert their control over directors and managers through their vote and particularly their takeover bid approval. Conversely, barriers or "entrenchment" practices may block unsolicited takeovers or defection of some shareholders in order to protect some specific shareholders or other stakeholders such as directors, managers, or employees. These entrenchment practices encompass restrictions on transferring shares, pre-emption rights, discounted prices for friendly shareholders, and different unequal voting rules for shareholders. These antidemocratic provisions can even be codified in a formal agreement among shareholders (a “shareholders' pact”). 
According to agency theory, a defective market for corporate control or the existence of entrenchment practices should impact negatively on R\&D decisions. However, previous results suggest that the shareholder model does not provide one single and coherent theory concerning the adoption or not of some shareholder-oriented practices (Hermalin and Weisbach, 1998; Bebshucks, 2002). For example, entrenchment practices can be interpreted as a reward to some shareholders $v i s-\grave{a}$-vis their strong commitment to the firm and its long-term development (see Hermalin and Weisbach, 1998). In this setting, an entrenched firm may regularly invest in R\&D. From a more general point of view, Stein (1988) argues that research expenditure provides opportunities for managers to gain inside information concerning future profit from innovation activities. He consequently suggests that entrenchment strategies are implemented by corporations with higher R\&D intensity and constitute a positive business signal for shareholders.

In France, large listed companies use unequal voting rights or shareholder's pacts more frequently than other countries (Goyer, 2003). The adoption of democratic practices by some French business groups may therefore dramatically change their governance system. Little is known, however, about the impact of voting rules on R\&D decisions. ${ }^{2}$ Despite the lack of coherent theory or empirical evidence, in this work we go along with the dominant literature and contend that:

H1a: Firms with democratic voting rules are more likely to conduct R\&D or to be Red intensive.

The communication practices implemented in companies provide information to the different stakeholders. In the Anglo-American archetype, the communication system is oriented toward shareholders and is supposed to provide better information than other corporate governance models. A communication system implementing modern tools and providing adequate "reliable" information to help shareholders, may also improve the ability of other stakeholders to insulate themselves from shareholders' influences (Höpner, 2005; Aoki, 2007). Furthermore, such a vertically oriented information system may be detrimental to horizontal information sharing among employees (Aoki, 2007) and in turn affect performance.

With respect to disclosure, the supposed lack of transparency of mainland European firms is often said to rely on nonsystematic compliance to international accounting standards, hampering clear control of decisions by shareholders. In terms of $\mathrm{R} \& \mathrm{D}$, managers in the United States or in France, for example, are likely to either choose to comply with their national accountancy schemes or to

\footnotetext{
${ }^{2}$ Some empirical works considered a global set of anti-takeover provisions likely to encompass many entrenchment practices. The different practices, especially the voting rules, are however not disentangled in these contributions where anti-takeover practices were found to be either detrimental (Meulbroek et al., 1990), neutral (Johnson and Rao, 1997) or positive (Pugh et al., 1992) for R\&D intensity.
} 
stick to international standards, in order to tilt the balance towards either expensing or capitalization (see Chambers et al., 2003). According to a 2002 Standard and Poor's survey, France actually ranked third right after the US and UK for transparency (see Khanna et al., 2004). This importance of information disclosure can be interpreted as a consequence of the importance of foreign institutional shareholders (Aguilera et al., 2008). Despite possible criticisms, we contend that:

H1b: Firms implementing a communication system directed towards improved shareholder knowledge are more likely to conduct R\&D or to be R\&D intensive.

Board practices usually aim to represent shareholders in order to advise and control managers. The distinction between directors' and managers' roles is often considered to be critical in the shareholder model and is materialized through the creation of a "chair separation" between the chair of the board and the chair of chief executive (Fama and Jensen, 1983). This chair separation can be also formalized through a "board charter" or reinforced by different specialized subcommittees, aimed at controlling multiple aspects of managers' decisions. These subcommittees are usually in charge of general auditing, compensating, nominating, and less frequently discussing scientific and technological strategies (see Spencer Stuart, 2005). Conversely, the influence of shareholders can be limited in boards organized with overlapping multi-year terms (a "staggered board") and which generate higher negotiation costs for potential hostile bidders (Bebchuk et al., 2002). However, board practices is likely to increase entrenchment such as having a dual chair can be once more interpreted as endogenously influenced by performance (Hermalin and Weisbach, 1998).

From an empirical point of view, the influence of different board entrenchment practices on R\&D decisions has rarely been explored. Mahoney et al. (1997) found that a dual chair does not influence R\&D intensity. ${ }^{3}$ Danielson and Karpoff (2006) also found that adopting "poison pills" 4 is one entrenchment practice which does not influence R\&D intensity.

A pro-shareholder board rule such as a dual chair can be neutralized by other practices involving external factors: boards can vote for cross-shareholdings or have director's interlocks (i.e. one director is the CEO of another firm and vice versa) with

\footnotetext{
${ }^{3}$ Other non-shareholders' rights governance practices implemented at the board level are no longer found to be conclusive regarding their impact on R\&D: when information disclosure is a threat the use of small boards is supposed to be less costly to manage but empirical studies have given little support to this idea (Boone et al., 2007 versus Zahra et al., 2000). Similarly, the hiring of "scientific" directors does not reduce agency costs in a conclusive way (Lacetera, 2001 or Barker and Mueller, 2002 versus Cockburn et al., 2000).

${ }^{4}$ Poison pills are the possibility for targeted shareholders to buy additional shares at a discount rate. The strategy does not require shareholder approval (and is thus not considered in voting rules here).
} 
strong social connections from college days (Kramarz and Thesmar, 2006). The last two dimensions are common in Japan or in France, thereby reducing the influence of outside directors and subsequently, according to agency theory, R\&D investment. ${ }^{5}$ These practices explain why boards have become increasingly constrained by institutions or laws into adopting certain shareholders' values (e.g. Aoki, 2007). In France, the influential Viénot reports in 1995 and 1999, carried out for the employers' association (MEDEF) recommended the separation of chairs but also the suppression of directors' interlocks and the creation of board committees. Even though several changes have occurred as a result of this recommendation, French CEOs are usually still able to maintain strong influence on strategies and organizations (Goyer, 2007) thanks to cross-shareholding and directors' interlocks. ${ }^{6}$ Despite current limitations, our third hypothesis is as follows:

H1c: Pro-shareholder board practices positively influence the likelihood of a firm to conduct ReD or to be RéD intensive.

A fourth dimension of corporate governance practices concerns compensation schemes. These are usually sophisticated and are often managed by dedicated committees, in order to align directors and managers with the shareholders' views (Hoskisson et al., 1993; Hitt et al., 1996). Managers with stock options are aligned with performance in an asymmetric way and thus are more likely to adopt risky behavior since failures, in R\&D projects, for example, and their subsequent negative impact on the firm's value do not diminish their expected rewards (i.e. options will not be exercised). Here, empirical evidence is surprisingly abundant but fails to provide robust evidence of the impact of detailed Anglo-American compensation practices on R\&D or innovation (see, among others, Eng and Shackell, 2001, or Holthausen et al., 1995, versus Cho, 1992, or, Xue, 2007). ${ }^{7}$ The introduction and influence of such compensation schemes may be mitigated when viewed in the national context. In France, the systematic provision of stock options since the 1990's is often only granted to a few top-employees and is subject to high tax rates. Second, they are counterbalanced by symmetric performance based compensation schemes (e.g. employee stock plans, profit sharing schemes) which have been mandatory since 1967, are well diffused (Dares, 2004), and are very popular due to the zero percent tax rate. As a consequence, French employees, including top managers with stock ownerships, are tied to shareholders' benefits but in a risk-averse way (Ryan and

\footnotetext{
${ }^{5}$ It can be argued that the decrease in R\&D is not due to a lack of alignment of directors but that interlocking is a means to diffuse technological information and innovation (see Mizruchi, 1996) which may reduce $R \& D$ investment.

${ }^{6} \mathrm{~A}$ law introduced in 2001 under the title "New Economic Regulations," slightly reduced the number of possible seats for the same director from eight to five.

${ }^{7}$ The lack of coherent results is also observed when the importance of managerial ownership is considered (Lacetera, 2001 versus Hoskisson et al., 2002 or Huimin and Mak, 2002).
} 
Wiggins, 2002) since a failure in R\&D may cut their annual bonuses. Taking into account the various beliefs about what changes in stock-option allocation may introduce regarding $\mathrm{R} \& \mathrm{D}$ decisions, we might expect that:

H1d: The use of shareholder oriented compensation practices is associated with a higher likelihood of a firm to conduct R\&D or to be R\&D intensive.

Beyond the four classifications of practices above, other global practices can be implemented by firms in order to defend shareholders' rights. From a global perspective, companies communicating and insisting on their governance policy and its importance at least acknowledge that some governance problems can occur between employees, directors, and shareholders. Companies signaling governance problems and solutions are more likely to protect their minority shareholders instead of undermining them. As a consequence, we expect these firms to be more respectful of shareholders' rights. We interpret this idea as:

H1e: The practice of promoting a visible governance policy is positively associated with the likelihood of a firm to conduct R\&D or to be R\&D intensive.

Governance policy statements, as the other governance practices presented above, are only formal aspects of governance and may be not carried out in reality. In some cases, certain governance practices simply cannot be really implemented as highlighted by Khanna et al. (2006), and may instead be only symbolic practices shaped in a certain way to influence shareholders' beliefs (Westphal and Zajac, 1998). We contend in the following sections that a corporate social responsibility rating agency can address the issue and is more likely to be capable of measuring those practices which are applied in reality. In this respect, litigation can also act as an interesting overall approximation for the real ability of firms to comply with national or international legal systems of governance or for their ability to negotiate with the plaintiffs. Defining the lack of litigation or conciliation as a shareholder-oriented practice of governance, we continue to follow the standard view here and contend that:

H1f: A lack of litigation is positively associated with the likelihood of a firm to conduct R\&D or to be R\&D intensive.

\subsection{Additivity and complementarity among governance practices}

The corporate governance literature is not clear on the relative contributions of existing practices in influencing a firm's value. On the one hand, articulation among multiple individual practices is not investigated while on the other hand, complementarity among the practices is often postulated but not demonstrated.

Little insight is provided by the literature on the type and number of governance practices implemented. A common analytic framework which can be applied to 
different existing practices is that the expected benefit from the adoption of a practice depends on the expected benefit from R\&D investment, compared to the expected costs of implementing the practice. Some provisions may therefore not be implemented due to low shareholder returns. ${ }^{8}$

In such a setting, the adoption of a one single practice is likely to be rare. As underlined by agency theory, the adoption of multiple practices may be required when the adoption of a single governance practice is not sufficient to control for heterogeneous agents in charge of uncertain activities and where agents' efforts are difficult to assess (Prendergast, 1999). In this context, when the practices implemented on the market for corporate control fail to provide adequate control, other governance practices such as board practices or compensation schemes are added by shareholders to achieve greater and balanced control (Agrawal and Knoeber, 1996). According to recent empirical results (Cremers and Nair, 2005; Bebchuk et al., 2009), certain entrenchment provisions (voting power, poison pills, and golden parachutes) are found to be more damaging than others in achieving long term performance and their eradication should yield higher net returns. Multiple practices are, however, difficult to consider at the same time and are thus often synthesized in the literature with indexes (La Porta et al., 1998; Gompers et al., 2003; Bebchuk et al., 2005), approximating the measure of intensity of alignment using the number of shareholder-oriented governance practices implemented. The positive coefficient obtained for the indexes (Gompers et al., 2003; Bebchuk et al., 2005) suggests that the effects of shareholder-oriented practices on performance are additive: every additional shareholder-oriented practice implemented adds a positive marginal benefit, whatever the combination among the adopted practices is. Even though we could not clearly define any one single governance practice as being more likely to influence R\&D decisions than another in a French context, we expect that the results on additivity hold for R\&D decisions:

H2 (additivity): The greater the number of practices defending shareholder's rights, the greater the likelihood of a firm to conduct R\&D or to be R\&D intensive.

The possible additivity of multiple governance practices is an important step, but is not appropriate in analyzing substitute, independent or complementary type

\footnotetext{
${ }^{8}$ The costs of a governance practice were not explicitly mentioned in Section 2.1. for the sake of brevity. They can be difficult to evaluate and encompass (Aguilera et al., 2008). Various costs include the following: the costs of compliance with the legislation (on accountancy rules, communication rules, human resource rules, taxes...); opportunity costs since time spent by different stakeholders to apply the rules could be used on other tasks; costs due to information disclosure which, in R\&D projects, can be considerable; reputational costs when firms do not apply rules or apply them despite their detrimental effects on some stakeholders. A further difficulty in this cost-benefit analysis is that, as underlined by Ichniowsky et al. (1997) regarding HRM practices, deciders may also not adopt practices due to the limited knowledge they have about their impact.
} 
interactions among governance practices (see Agrawal and Knoeber, 1996; Cremers and Nair, 2005; Nelson, 2005; Berry et al., 2006; Aguillera et al., 2008). In a shareholder-centered model, communication with owners can be interpreted as a complement to democratic voting rules: minority shareholders' votes can be useful only if the shareholders are well informed. In another setting, some shareholder-oriented practices can undermine the participation of stakeholders (Aguillera et al., 2008). For example, in a governance model such as the Japanese one, personal compensation schemes may destroy valuable information sharing practices (Aoki, 2007).

Complementarity is critical in order to define national corporate governance systems as coherent and stable sets of practices which are shaped by and are complementary to, their institutional and industrial environments (e.g. La Porta et al., 1998; Hall and Soskice, 2001; Aoki, 2007; Aoki and Jackson, 2008). In this respect, theoretical modeling demonstrates that the existence of complementarity means that the link between costs and gains of one practice are dependent on other practices; the adoption of one practice or group of practices may increase the marginal return in the adoption other governance practices (Milgrom and Roberts, 1990: 514; Topkis, 1998). The existing problem of governance practice selection, based on cost-benefit analysis of governance practices, must therefore also take into consideration complementarity effects in order to find possible efficient and stable equilibria (Danielson and Karpoff, 1998; Aoki, 2001; Cremers and Nair, 2005).

There is a critical lack of empirical results on the comparative performances of different governance systems in terms of R\&D. The only rough and puzzling results concern industry-financed business $\mathrm{R} \& \mathrm{D}$ expenditures as a percentage of the value added in industries which, over the last 25 years, have been found to be greater in Japan, Sweden, Switzerland, and Germany than in the United States or the UK (OECD, 2008). This macro indicator suggests that, over this period, the shareholder model did not succeed in maintaining R\&D investment, especially in the UK. ${ }^{9}$ Despite this result, we set a third hypothesis as follows:

H3 (complementarity): Firms implementing a comprehensive set of proshareholder governance practices are more likely to conduct R\&D or to be R\&D intensive due to complementarity effects between these practices.

\footnotetext{
${ }^{9}$ The evolution over the last 30 years of industrial R\&D investment in UK is particularly problematic if one considers that the evolution depends on the shareholder corporate governance model. However, defenders of the shareholder model can argue that the shareholder system of governance has enabled not only a fast market reorientation and reallocation of resources from traditional UK manufacturing industry to high value added services where there are difficulties in measuring R\&D activities, but also allowed the UK to be in a better position than French or German counterparts at creating biotech start ups based on venture capital.
} 
H3 has important implications on our previous hypotheses. The introduction, one by one, of practices leading to a nonsignificant coefficient no longer means that the considered practice has little or no impact as there may in fact be some impact if this practice is combined with others. The possible existence of complementarity casts doubt particularly on previous results which emphasized the existence of a hierarchy among practices without checking for H3 (e.g. Bebchuk et al., 2009). In other words, $\mathrm{H} 3$ may hold without $\mathrm{H} 1$ being validated. Furthermore, providing complementarity among practices holds, an intermediate number of practices could even be implemented without influencing R\&D decisions ( $\mathrm{H} 3$ holds but $\mathrm{H} 2$ is ruled out). The possible existence of complementarity among different shareholder-oriented practices (H3) is therefore critical in order to properly interpret the results obtained for $\mathrm{H} 1$ and $\mathrm{H} 2$.

\subsection{Cross-listing and control pyramids as governance practices}

The analysis of the role of the shareholder on the French system of corporate governance often overlooks the fact that French MNEs have global investors. MNEs can reduce the effects of "national" institutional constraints by combining different national regulations. In particular, mainland European firms listed in New York can bring back some governance practices from abroad. Following Doidge et al. (2004) and Karolyi (2006), the decision to cross-list a firm's shares on a foreign exchange market can be considered as a means of constraining managers by using additional legal mechanisms and consequently potentially influencing their R\&D decisions. More precisely, such measures are more likely to constrain managers from a mainland European governance model into adopting shareholder rules which apply to United States or UK stock markets. Despite the early empirical article by Blass and Yosha (2003), which found no significant difference in R\&D intensity between Israeli firms listed on the Israeli or United States stock markets, to our knowledge no study has yet explored the influence of cross-listing on R\&D decisions. We contend that:

H4: A mainland European firm belonging to a corporation which is listed on the New-York or London Stock Exchange is more likely to conduct R\&D or to be R\&D intensive.

Similarly, a sensible step forward would be to adopt the view of US large corporations as a heterogeneous assembly of firms and divisions where differentiation occurs and where different governance systems are required (Williamson, 1975; Hoskisson et al., 1993). On the contrary, the mainland European, Asian, or Latin-American solution to differentiation is an integration of activities through the more systematic creation of a large chain of affiliates (La Porta et al., 1999; Claessens et al., 2000, Faccio and Lang, 2002; Morck et al., 2005). The use of this "control pyramid" as a governance mechanism reinforces shareholders' interlocks or unequal voting shares, enabling a minority to control a substantial part of listed 
capital, and in turn neutralizing the market for corporate control (Morck et al., 2005). This additional entrenchment strategy limits access to information for under-informed outside investors. In France, no disclosure requirements are, for example, mandated by national security laws concerning the activities of firms' nonlisted affiliates. From the literature, we contend that a control pyramid can be an effective barrier to the diffusion of shareholder-oriented practices and that the strengthening of shareholders' rights may be adopted only by the ultimate owner. We thus assert that it influences $\mathrm{R} \& \mathrm{D}$ decisions in the pyramid:

H5: An affiliate with a lower position in the "control pyramid" is less likely to conduct R\&D or to be R\&D intensive

\section{Methods}

\subsection{Sample}

Our sample is the result of the matching of four separate data sets. The first set of data on corporate governance was provided by Vigéo, an independent French corporate social responsibility rating agency. A set of scores, available at the business group level, categorizes firm performance on the basis of precise questioning together with documents and information gathered regarding the policies, implementation, and results of the management system in place. With respect to corporate governance aspects, in 2000 Vigéo tracked 19 types of corporate governance practices implemented by 116 of the SBF-120 firms which comprise the 120 most highly capitalized and most liquid French stocks traded in Paris (see Paris Stock Exchange, 1996). The 19 sustained aspects, listed in Table 1, are assessed on a 100-point scale, according to their effectiveness at representing shareholders' interests and rights: for example, the lack of a double-voting share induces a high score since it is supposed to defend minority shareholders' interests. The 19 scores are given by industry experts and are relative to the industry average (considered to be 50 and defined at the two-digit level of the NACE classification) of the scored business groups. Hence, a score of 75 on stock options means that the scored firm implements this antientrenchment practice less than other firms do in the same industry. Conversely, a zero score means that the firm lags behind, implementing this entrenchment strategy practice to a greater extent than others in the same industry.

For confidentiality reasons, the rating agency gave us only 9 aggregated indexes built on the 19 basic scores (Table 1) for the year 2000. The 9 given scores were computed as the average of the 19 basic scores. For example, the "voting rules" index is the average of three basic scores given on the shareholder-oriented use of the double-voting share, voting limitations and shareholder's pact. When the three aspects were rated at 40,55, and 75, respectively, the voting rule index was set to 170/3. The properties and interpretations of the nine indexes are similar to the ones on basic indexes. As advocated earlier, the scores given by experts are an efficient means of 
Table 1 The 19 rated governance practices and 9 available indexes

Nineteen aspects of rated governance practices

(not available due to confidentiality reasons)
Nine discretized indexes

(available)

$\mathrm{G}_{11} \quad$ How does the executive committee express its conception of shareholders and corporate governance in global corporate strategy?

$\mathrm{G}_{12}$ Is there any governance charter?

$\mathrm{G}_{1}{ }^{\text {bin }}$ Governance Policy

$\mathrm{G}_{13}$ Is there a chapter dedicated to corporate governance in the annual report?

$\mathrm{G}_{20} \quad$ It there a dedicated structure for relations with shareholders?

$\mathrm{G}_{30}$ What are the tools of communication implemented?

$\mathrm{G}_{40} \quad$ Self-evaluation concerning communication

$\mathrm{G}_{50}$ What does the group do to incite and facilitate shareholder commitment at annual general meetings?

$\mathrm{G}_{61} \quad$ Is there any double-voting share?

$\mathrm{G}_{62}$ Is there any voting limitation?

$\mathrm{G}_{63}$ Is there any shareholder's pact?

$\mathrm{G}_{71}$ Is there a structure of board of directors / supervisory board?

$\mathrm{G}_{72}$ Is there a dual chair?

$\mathrm{G}_{73}$ Is there a board charter?

$\mathrm{G}_{74}$ Is there a staggered board?

$\mathrm{G}_{75}$ Is there any dedicated committee (audit, nominating, Governance)?

$\mathrm{G}_{81}$ Is there a compensation committee?

$\mathrm{G}_{82} \quad$ Are there stock options?

$\mathrm{G}_{83}$ Directors' fees?

$\mathrm{G}_{90}$ Have there been any litigations or lawsuits initiated by shareholders within the last 12 months?

$\mathrm{G}_{2}$ bin Communication structure

$\mathrm{G}_{3}{ }^{\text {bin }}$ Communication tools

$\mathrm{G}_{4}{ }^{\text {bin }} \quad$ Communication quality

$\mathrm{G}_{5}$ bin Annual meeting

$\mathrm{G}_{6}{ }^{\text {bin }} \quad$ Voting rules

$\mathrm{G}_{7}^{\text {bin }}$ Board organization

$\mathrm{G}_{8}$ bin Compensation schemes

$\mathrm{G}_{9}^{\text {bin }} \quad$ Litigations

The different concepts used by Vigéo are briefly defined and presented in Section 2.1.

G11 to G90 are scores measuring the importance of governance practices considered from a shareholder protection point of view. Highest scores reflect a better defense of minority shareholders. The 19 scores are based on a 100 scale. The 9 indexes $G_{1}$ to $G_{9}$ are set to one if the average of scores within the considered category is higher than the average for the industry (50). For example, a firm with $G_{6}{ }^{\text {bin }}=1$ when $\left(G_{61}+G_{62}+G_{63}\right) / 3>50$, represents a firm which is more democratic than the average firm belonging to the same industry. 
checking for real governance practices as compared to nonapplied or symbolic practices.

A second set of data comprises R\&D data from 2000 and 2001 from the national mandatory survey on R\&D (Statistics Office-Ministry of Research and Higher Education) and also R\&D tax credit data files for 2000 and 2001 (Direction de la Technologie-French Ministry of Research and Higher Education). A common caveat in the literature studied is that $\mathrm{R} \& \mathrm{D}$ data are provided through $\mathrm{R} \& \mathrm{D}$ surveys whose definition usually hardly fits with the informal R\&D activities undertaken by firms, especially in SMEs or services (see Kleinknecht et al., 1991). This can be a serious problem when many affiliates belong to the bank and insurance sectors or are in charge of financial activities for industrial business groups. The combination of the two sources of data on R\&D mitigates this problem.

The link between rated corporate and individual firms was made thanks to the Liaison Financière (LIFI) data set (INSEE). The year 2000 files provided information on the different affiliates within a business group. A firm in LIFI is considered to be controlled when the owner holds $>50 \%$ of the shares. In 2000, 83,126 firms located in France were listed as belonging to 10,438 business groups. An SBF-120 group is thus observed either at the aggregated level, or at the individual level. Among the available 116 rated business groups, the Wanadoo, Dior, Rexel, Lapeyre, or Equant groups are not included in our sample since they are controlled by larger listed business groups; M6 Television is also deleted since the business group is not satisfactorily defined. Further deletions of firms were necessary due to missing employment values, especially for small affiliates in services, or firms with noncommercial activities. We thus obtained a final set of 41,273 firms controlled by 9667 business groups. Among these firms, 5528 firms belong to 110 SBF-120 business groups.

The different sources were matched as follows: the 5528 individual firms were first matched with $R \& D$ data. Then, group-level data were matched adding three types of information to each individual firm: (i) information from LIFI on its rank in the pyramid control; (ii) general control variables from LIFI on its business group; and (iii) corporate governance variables on its business group.

\subsection{Measures of $R \& D$ variables}

At the firm or business group level, we first calculated R\&D intensity (hereinafter R\&DI) for the year 2001, defined as the internal R\&D budget divided by the number of employees (to mitigate the intragroup influence of transfer pricing, or a lack of sales). At the firm level, we took the gross R\&D budget and subtracted the R\&D amounts contracted out to other French or foreign affiliates belonging to the same business group. Such a variable could not be implemented directly, however, since very few firms belong to the same industry and it was thus impossible to check for differences among competitors within the same industry. To deal with this difficulty, we proposed to compute two different variables: first, R\&DYES is 1 when the firm declared it invested in $R \& D(R \& D I>0)$, otherwise null. For the $R \& D$ active firms, the 
quartile values $Q_{1}, Q_{2}$, and $Q_{3}$ for $R \& D$ intensity for every industry were defined at the two-digit level of the NACE classification. We then obtained an ordered R\&D intensity (OR\&DI) polytomic variable as follows: $O R \& D I=1$ if $0<R \& D I \leq Q_{1}$, is 2 if $\mathrm{Q}_{1}<\mathrm{R} \& \mathrm{DI} \leq \mathrm{Q}_{2}$, is 3 if $\mathrm{Q}_{2}<\mathrm{R} \& \mathrm{DI} \leq \mathrm{Q}_{3}$, is 4 if $\mathrm{Q}_{3}<\mathrm{R} \& \mathrm{DI}$ computed for all 31 NACE industries (two digit level).

The $2001 \mathrm{R} \& \mathrm{D}$ survey was considered as the main data source here. The R\&D budget declared in the 2001 tax credit files was however added if the first R\&D intensity value was nil. This rule enabled us to grasp informal or service R\&D budgets which are not usually well captured by standard R\&D questionnaires.

\subsection{Measures of governance practices}

The corporate governance practices were scored at the business group level. We decided to keep the maximum of information from the nine indexes provided by Vigéo which were gathered into six governance categories as outlined in Section 2.1.: Governance policy $\left(G_{1}\right)$, communication $\left(G_{2}-G_{5}\right)$, market for corporate control $\left(G_{6}\right)$, board organization $\left(G_{7}\right)$, compensation schemes $\left(G_{8}\right)$, and litigations $\left(G_{9}\right)$. However, in order to cope with the issue of robustness, the nine continuous governance indexes were discretized and transformed into nine dummies $\left(G_{k}{ }^{b i n}\right.$, $\mathrm{k}=1, \ldots, 9$ ) which equal 1 when the given average score is $>50$, that is to say, when the shareholders' rights are more protected than in other firms or business groups belonging to the same industry (see notes in Table 1). This set of nine dummies is designated GOV PRA.

Following Gompers et al. (2003), we also computed a G Index as the simple sum of the nine governance dummies ( $G$ Index $=\sum_{k=1}^{9} G_{\mathrm{k}}^{\mathrm{bin}}$ ).

As mentioned, such an index is, however, a black box where the relationship between practices is not explicit. In order to investigate such interactions, we proposed substituting GOV PRA with cluster indicators-based on the Wards' linkage method. ${ }^{10}$ The cluster analysis was carried out on the nine scores and enabled us to delineate two main classes of business groups (see Table 2 for an ex post description of these groups): in a similar fashion to Gompers et al. (2003), the group designated "Democratic" comprises firms (Democratic $=1,0$ otherwise) with governance practices which favor shareholders' rights and are implemented in a more systematic way. Conversely, the "Dictatorial" cluster is the set of firms with poor interest in governance practices oriented toward shareholders' views (Dictatorial $=1,0$ otherwise).

\footnotetext{
${ }^{10}$ We use a hierarchical cluster analysis where the method for calculation of cluster-to-cluster distance is the Ward's distance. The latter is computed as the increase in the error sum of squares. After merging two clusters into a single one, the Ward's algorithm seeks to minimize the increase in error sum of squares at each step. Ward's method is thus an efficient way to obtain clusters with minimized variance.
} 
Table 2 Descriptive statistics of business group level variables $\left(N_{g}=110\right)$

\begin{tabular}{|c|c|c|c|c|c|c|c|c|c|c|c|c|}
\hline Row & Variables & Mean & SD & (1) & (2) & (3) & (4) & (5) & (6) & (7) & (8) & (9) \\
\hline (1) & Governance policy & 0.39 & 0.49 & 1 & & & & & & & & \\
\hline (2) & Communication structure & 0.32 & 0.47 & $0.34^{*}$ & 1 & & & & & & & \\
\hline (3) & Communication tools & 0.37 & 0.48 & 0.31 * & 0.29 & 1 & & & & & & \\
\hline (4) & Communication quality & 0.38 & 0.49 & 0.26 & $0.39 *$ & $0.33^{*}$ & 1 & & & & & \\
\hline (5) & Annual meeting & 0.31 & 0.47 & $0.42 *$ & $0.32 *$ & $0.44^{*}$ & 0.27 & 1 & & & & \\
\hline (6) & Voting rules & 0.23 & 0.42 & $0.40^{*}$ & $0.32 *$ & 0.20 & $0.54^{*}$ & $0.43^{*}$ & 1 & & & \\
\hline (7) & Board organization & 0.54 & 0.50 & $0.46^{*}$ & 0.22 & $0.36^{*}$ & $0.33^{*}$ & $0.43^{*}$ & 0.19 & 1 & & \\
\hline (8) & Compensation schemes & 0.36 & 0.48 & $0.39 *$ & $0.32^{*}$ & 0.22 & $0.40^{*}$ & 0.31 * & $0.36^{*}$ & $0.44^{*}$ & 1 & \\
\hline (9) & Litigations & 0.22 & 0.42 & $0.33^{*}$ & 0.24 & 0.04 & $0.48^{*}$ & 0.24 & $0.47^{*}$ & 0.18 & $0.38^{*}$ & 1 \\
\hline (10) & Listed in NY or London & 0.17 & 0.38 & 0.14 & 0.06 & 0.21 & $0.35^{*}$ & 0.10 & 0.03 & 0.07 & 0.13 & 0.06 \\
\hline
\end{tabular}

${ }^{\star}$ Significant at $5 \%$.

Following Blass and Yafeh's (2001) study on cross-listed Israeli firms, we computed a dichotomous variable defined as NY\&LSE. NY\&LSE equals 1 for French firms registered on the New York or London Stock Exchanges in 2000. All these firms belonged to the French SBF120. One restriction was that only 19 French business groups were cross-listed, representing 1876 firms. Due to this small number of French cross-listed firms we had no means of evaluating differences between the two Anglo-American governance systems (see Tylecote et Ramirez, 2006) and thus no means to disentangle their dissimilar influences on $\mathrm{R} \& \mathrm{D}$ decisions.

Finally, if an affiliate was directly controlled (here the control rate was 50\% or more) by the parent firm (always ranked at zero), the rank variable (RANK) was set to one. If the firm was indirectly controlled by the direct affiliate, the rank was set to two and so on (the maximum value was 15). This variable approximated the firm's position in the control pyramid and was thus available at the individual firm level.

\subsection{Control variables}

Following other empirical work dealing with R\&D investment or intensity, we used several control variables available at the firm level for 2000. First, the log value for the number of employees was found (SIZE). The variable was also computed at the second order $\left(\mathrm{SIZE}^{2}\right)$. At the firm level, the LIFI business group database also gave the control ranking for each affiliate.

Industry type is an important determinant of R\&D activities. The R\&D scores computed at the NACE two-digit level should have eliminated industry differences among the SBF120 firms. However, some heterogeneity may not have been controlled for here. To check for this possible effect, we introduced industry-fixed effects. The restricted number of R\&D investors, however, led us to restrict the 
number of industry dummies to three dichotomous variables (designated TECH): HT, MT and LT equaled to 1 when the firm belonged, respectively, to high tech, medium tech, or low tech industries, based on average industry R\&D expenditure (see OECD, 1997).

The individual business group's commitment to $\mathrm{R} \& \mathrm{D}$ does in fact influence the affiliate's own R\&D investment. To take this interaction into account, we calculated GRR\&DI ${ }^{\text {others }}$, which is the intensity of other affiliated firms owned by the same business group. GRSIZE ${ }^{\text {others }}$ measures the size of the rest of the business group for a firm i. This is the number of employees (taken in log) of the same business group who work in other affiliates. The size and R\&D intensity of the entire business group are GRSIZE and GRR\&DI, respectively.

Finally, the two different R\&D definitions used for the explained variable may have been a source of bias which in turn was controlled for through the introduction of a dummy (R\&DTC) as an explanatory variable which equaled 1 when the OR\&DI was computed using R\&D tax credit data.

\subsection{The econometric method}

The micro-level data set offers several advantages compared to previous studies. First, the influence of governance practices is captured at the firm level and not at the business group level. Second, it is useful to be able to control for the diversity of activities and decisions inside large business groups. This control can be carried out at business group (clusterized residuals) or firm (sectoral dummies) levels. Moreover, the micro-level approach enables us to control for both vertical differences at the firm level (the position in the control pyramids) and global strategy at the business group level (cross-listing).

More precisely, our main model includes firm variables (subscript $i$ ), business group variables (subscript $g$ ) and a time variable (subscript t with $t=2000$ ). We distinguish between the decision to invest in $\mathrm{R} \& \mathrm{D}$ (Do I invest into $\mathrm{R} \& \mathrm{D}$ or not?) from the decision on the level of R\&D (How much do I invest?). We thus obtain a Heckman ordered probit model with a selection equation:

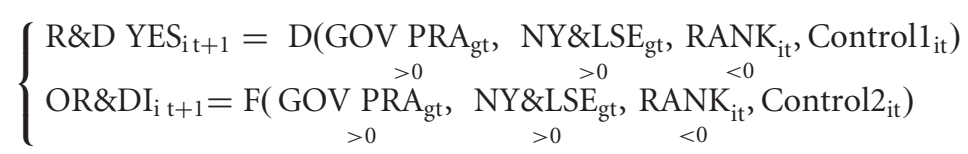

The subscripts refer to the expected signs ( $\mathrm{H} 1, \mathrm{H} 4$, and $\mathrm{H} 5)$; the two main sets of control variables used in the article are:

$$
\begin{aligned}
\text { Control1 }= & \left\{\text { SIZE, } \text { SIZE }^{2}, \mathrm{GRSIZE}^{\text {Others }}, \mathrm{GRSIZE}^{\mathrm{Others} 2}, \mathrm{GRR} \& \mathrm{DI}^{\mathrm{Others}},\right. \\
& \text { R\&DTC, TECH }\} \text { and } \\
\text { Control2 }= & \left\{\text { SIZE, GRSIZE }{ }^{\text {Others }}, \text { GRR\&DI }{ }^{\text {Others }}, \text { R\&DTC, TECH }\right\} .
\end{aligned}
$$


According to $\mathrm{H} 2$, a positive effect of the $\mathrm{G}$ index or Democratic variable, replacing the GOV PRA variables in both R\&D equations, is also to be anticipated.

Complementarity $(\mathrm{H} 3)$ is an econometric problem since it hampers the accurate identification of parameters associated with governance practices. According to Ichniowski et al. (1997), two strategies can be implemented to test the hypothesis of complementarity in a simple fashion. In the first strategy, the Democratic cluster brings additional information to the $\mathrm{R} \& \mathrm{D}$ equations whereas a marginal change among individual practices has no significant influence on R\&D. Model (2) is thus a set of nine models, where the coefficient of each governance practice $\left(G_{\mathrm{kg}}^{\mathrm{bin}}\right.$, $k=1-9$ ) introduced alone along with the Democratic dummy is not expected to be significantly different from zero. The second strategy is to test whether the magnitude of the effect of the governance practice system on $\mathrm{R} \& \mathrm{D}$ is greater than the sum of the marginal effects of adopting each governance practice. If positive interaction between practices occurs, the Democratic cluster will remain significant even if all practices ( $G_{1}^{\text {bin }}$ to $G_{9}^{\text {bin }}$ ) are introduced at the same time in the model. The Model (3) is thus similar to equation (1) but Democratic is added simultaneously along with the other 9 governance practice variables and is expected to be positively linked to R\&D.

For the sake of brevity here, some other econometric issues including robustness aspects are considered in the Appendix A.

With regard to control variables, size is expected to have a positive influence. This effect is anticipated either at the individual or business group level: a large affiliate is able to absorb R\&D costs more easily and an affiliate is also more likely to amortize the cost of $\mathrm{R} \& \mathrm{D}$ over the whole group's market. We also consider that the use of external knowledge requires important absorptive capacities to acquire and adapt knowledge for productive purposes. The R\&D intensity of other firms belonging to the same group is, therefore, expected to have a positive influence on the R\&D intensity of a single affiliate. The complementary effect on R\&D is considered dominant here compared with the substitution effect that occurs when a specialized R\&D center or firm exists. Finally, the RDTC parameter is expected to be positive in both equations: $R \& D$ tax credit firms are all included in $R \& D$ firms; $R \& D$ tax credit can include non-R\&D expenditure or intragroup $R \& D$ payments.

\section{Results}

\subsection{Descriptive statistics}

From the descriptive statistics in Table 2, we can see that the SBF120 firms are more likely to adopt shareholder-oriented board practices (54\%), at the same time pay more attention to governance policies (39\%), implement proper communication tools and compensation schemes (36\%). Instead, these same firms are less likely to 
Table 3 Description of governance clusters

\begin{tabular}{llll}
\hline & Variable & $\begin{array}{l}\text { Democratic, } N=61 \\
\text { Mean }\end{array}$ & $\begin{array}{l}\text { Dictatorial, } N=49 \\
\text { Mean }\end{array}$ \\
\hline $\mathrm{G}_{1}^{\text {bin }}$ & Policy & 0.62 & 0.10 \\
$\mathrm{G}_{2}^{\text {bin }}$ & Communication structure & 0.51 & 0.08 \\
$\mathrm{G}_{3}{ }^{\text {bin }}$ & Communication tools & 0.59 & 0.08 \\
$\mathrm{G}_{4}{ }^{\text {in }}$ & Communication quality & 0.66 & 0.02 \\
$\mathrm{G}_{5}^{\text {bin }}$ & Annual meetings & 0.51 & 0.06 \\
$\mathrm{G}_{6}{ }^{\text {bin }}$ & Voting rules & 0.39 & 0.02 \\
$\mathrm{G}_{7}{ }^{\text {in }}$ & Board organization & 0.82 & 0.19 \\
$\mathrm{G}_{8}^{\text {bin }}$ & Compensation schemes & 0.59 & 0.06 \\
$\mathrm{G}_{9}^{\text {bin }}$ & Litigations & 0.39 & 0.00 \\
$\mathrm{NY \& LSE}$ & Listed in NY or London & 0.26 & 0.00 \\
\hline
\end{tabular}

introduce democratic-voting rules $(3 \%)$ or to manage litigations with shareholders $(22 \%)$.

Table 2 confirms that governance practices are often positively correlated, suggesting the possible existence of some collinearity but also of complementarity effects. However, cross-listing is positively correlated with communication quality only.

The results reported in Table 3 show that "democratic" firms represent 55\% of our set of SBF 120 firms. These democratic French firms are quite good communicators with known governance policies, with pro-shareholder board practices $(82 \%)$ and shareholder-oriented compensation schemes (59\%). Voting rules are, however, still detrimental to shareholders' power within this cluster (39\%). In the dictatorial category, very few practices are introduced even though board organizations are implemented by one fifth of firms. Finally, Table 3 reports that Democratic firms are more often listed abroad.

The cluster analysis confirms that several corporate governance models may cohabit within a single institutional environment. According to the cluster analysis, French "democratic" firms are more shareholder oriented than their competitors having, on average, 5.5 governance practices out of the possible 9 , which highlights that they are more shareholder oriented than the industry average (see Table 4) whereas dictatorial firms almost never commit significantly to shareholders' rights (1.32). The "democratic" governance cluster is different from the shareholder archetype: many firms do not implement all the core shareholder-oriented practices and instead continue to keep entrenchment practices. 
Table 4 Descriptive statistics of firm level variables

\begin{tabular}{|c|c|c|c|c|c|}
\hline Sample & All firms & $\begin{array}{l}\text { SBF120 } \\
\text { selected firms }\end{array}$ & $\begin{array}{l}\text { Democratic } \\
\text { firms }\end{array}$ & $\begin{array}{l}\text { Dictatorial } \\
\text { firms }\end{array}$ & $\begin{array}{l}\text { NY\&LSE } \\
\text { firms only }\end{array}$ \\
\hline $\begin{array}{l}\text { Number of business } \\
\text { groups }\end{array}$ & 9667 & 110 & 61 & 49 & 19 \\
\hline \multirow[t]{2}{*}{ Number of firms } & 41273 & 5528 & 3342 & 2186 & 1876 \\
\hline & Mean (SD) & Mean (SD) & Mean (SD) & Mean (SD) & Mean (SD) \\
\hline G Index & & $3.88(2.66)$ & $5.47(2.01)$ & $1.32(1.13)$ & $4.71(2.47)$ \\
\hline SBF120 & $0.14(0.35)$ & $1(0)$ & $1(0)$ & $1(0)$ & $1(0)$ \\
\hline OR\&DI $=0$ & & $0.91(0.29)$ & $0.89(0.32)$ & $0.93(0.26)$ & $0.88(0.32)$ \\
\hline OR\&DI $=1$ & & $0.02(0.15)$ & $0.03(0.18)$ & $0.03(0.17)$ & $0.04(0.19)$ \\
\hline$O R \& D I=2$ & & $0.02(0.13)$ & $0.01(0.09)$ & $0.01(0.09)$ & $0.01(0.09)$ \\
\hline OR\&DI $=3$ & & $0.02(0.14)$ & $0.03(0.17)$ & $0.02(0.12)$ & $0.03(0.17)$ \\
\hline$O R \& D I=4$ & & $0.03(0.17)$ & $0.04(0.20)$ & $0.02(0.14)$ & $0.04(0.19)$ \\
\hline RANK & $1.79(1.53)$ & $3.38(2.34)$ & $3.25(1.77)$ & $3.59(3.04)$ & $3.27(1.26)$ \\
\hline SIZE & & $4.02(1.83)$ & $4.06(1.83)$ & $3.95(1.81)$ & $4.06(1.82)$ \\
\hline $\mathrm{SIZE}^{2}$ & & $19.49(15.96)$ & $19.87(15.89)$ & $18.87(16.05)$ & $19.80(15.78)$ \\
\hline GRSIZE $^{\text {others }}$ & & $10.42(1.27)$ & $10.43(1.14)$ & $10.40(1.52)$ & $10.86(0.82)$ \\
\hline GRSIZE & $6.59(2.52)$ & $10.45(1.20)$ & $10.45(1.08)$ & $10.44(1.39)$ & $10.87(0.80)$ \\
\hline GRR\&DI $\left.\right|^{\text {thers }}$ & & $2.41(5.64)$ & $2.85(5.86)$ & $1.73(5.19)$ & $2.61(4.28)$ \\
\hline GRR\&DI & $0.93(4.12)$ & $2.45(5.68)$ & $2.86(5.84)$ & $1.79(5.35)$ & $2.64(4.39)$ \\
\hline R\&DTC & & $0.03(0.16)$ & $0.02(0.14)$ & $0.03(0.18)$ & $0.02(0.14)$ \\
\hline
\end{tabular}

One interpretation of the empirical cluster analysis is that some French firms adopt a hybrid model 'of corporate governance (Aoki and Jackson, 2008). The French "democratic" model reflects a hybrid between the shareholder model used in Common-law countries and that of the traditional French stakeholder model. In such an intermediate model, shareholders' power is limited by undemocratic voting rules and, as one can imagine, by certain hidden board practices (cross-shareholding, directors' interlocks are not measured here) which counterbalance some recently implemented shareholder-oriented board practices such as dedicated committees or dual chairs, adopted to please institutions (e.g. the cited Viénot reports). The result is consistent with previous articles exploring the influence of the shareholder archetype model on stakeholder models, be they in Japan (Aoki, 2007) or in Germany (Fiss and Zajac, 2004).

Table 4 displays further characteristics of the 5528 firms belonging to 110 business groups from the SBF120 Paris Stock Exchange. On average, firms from SBF120 business groups are ranked higher than non-SBF120 firms. Similarly, they are 
naturally larger and constitute larger business groups. Table 4 also suggests that R\&D intensity is higher in SBF120 than in non-SBF120 business groups. On average, firms belonging to a SBF-120 business group are ranked around 3.4 in the control pyramid. $\mathrm{R} \& \mathrm{D}$ activity or intensity is found to be higher, both at firm and group levels in democratic firms than in dictatorial firms. A similar result is seen for cross-listed firms which are more democratic that dictatorial.

\subsection{Econometric results}

Two tables present the results obtained on Model (1). Table 5 presents the impact of each governance practice [columns $(\mathrm{a}-\mathrm{i})$ ] when they are introduced one by one, in order to avoid multicollinearity problems. Results show that 8 out of 9 practices positively and significantly influence the probability of R\&D investment, which gives support to the $\mathrm{H} 1$ hypothesis, except for the practice of having a "minority shareholder friendly" annual meeting (H1b).

Table 6 [columns $(\mathrm{a}-\mathrm{i})$ ] provides the same conclusions on the positive influence of pro-shareholder governance practices, but only 6 out of 9 shareholder-oriented practices are significantly and positively related to R\&D intensity. Voting rules, Governance Policy and Communication practices as well as compliance to legal practices are all found to positively influence $\mathrm{R} \& \mathrm{D}$ intensity. $\mathrm{H} 1 \mathrm{c}$, on the board organization, and H1d on the compensation practices, are however not supported for R\&D intensity even though they are found to be influential on the likelihood of investing in R\&D. The result on these two governance practices which are core to the shareholder model and to agency theory suggests that the model is not completely adapted to the French context. As contended before, the nonsignificance of some parameters can also be due to some complementarity effects.

When introduced together [column (j) in Table 5 or 6] parameters of the different governance practices become almost unidentifiable due to collinearity. An LR test for both equations shows that the introduction of the whole set of governance practice variables significantly improves the overall model. ${ }^{11}$ A general result is thus that several shareholder-oriented practices positively influence the likelihood of R\&D investment and the intensity of R\&D commitment.

The introduction of the Democratic variable, taking dictatorial firms as a reference, leads to similar results: democratic firms have a higher likelihood of R\&D investment and intensity when compared to other similar firms [column (k) in Tables 5 and 6]. Second, column (l) in both tables shows the positive impact of the $G$ index on R\&D (the introduction of a G Index squared does not significantly increase the Log-Likelihood). The impact of pro-shareholder governance practices is therefore found to be positive and also additive, as it supports H2. These results

\footnotetext{
${ }^{11}$ The critical value is $104.9(P<0.01)$ for the profit part and $25.6(P<0.01)$ for the R\&D intensity part as reported in columns (j) of Table 5 and Table 6 .
} 


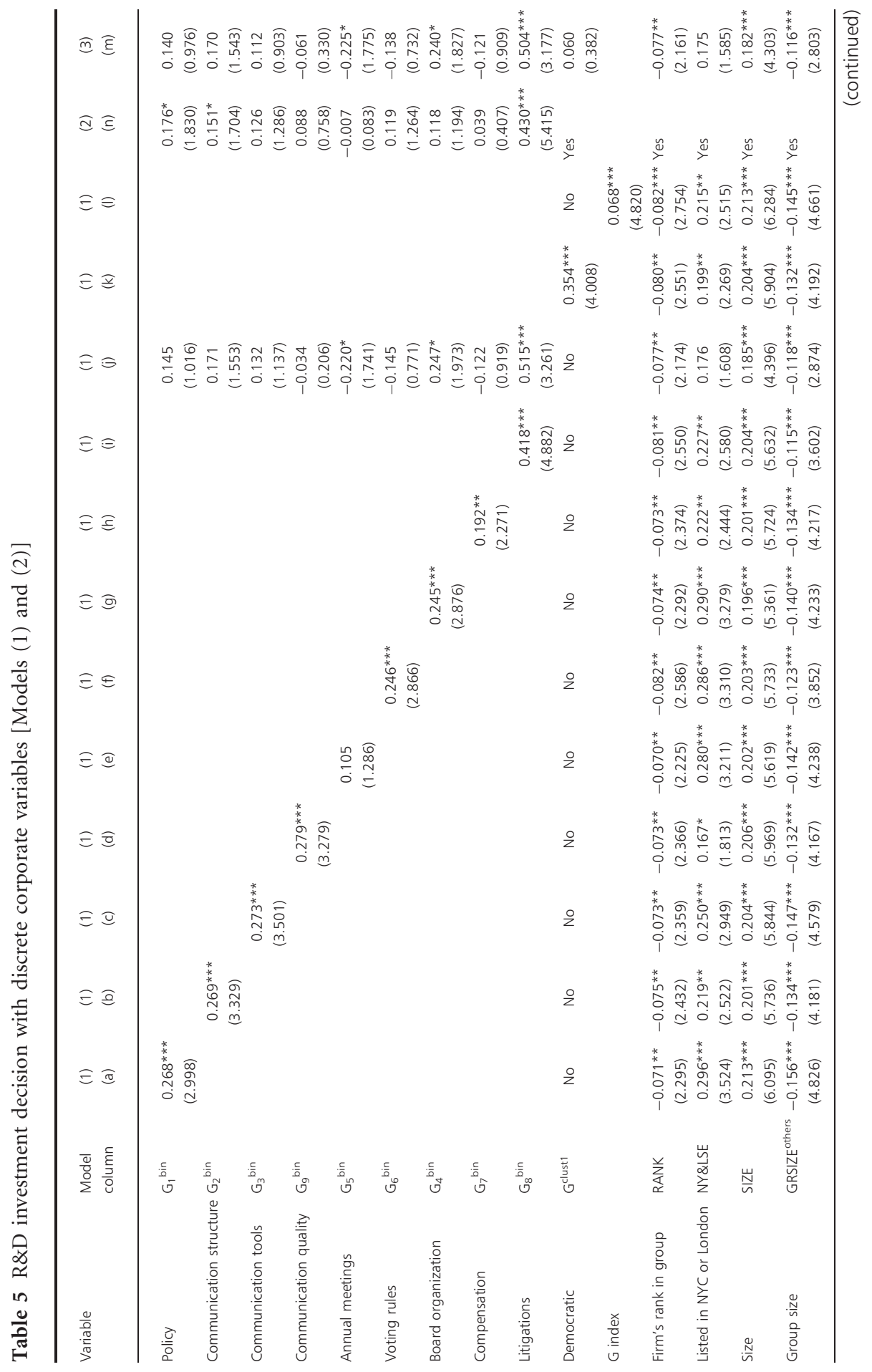




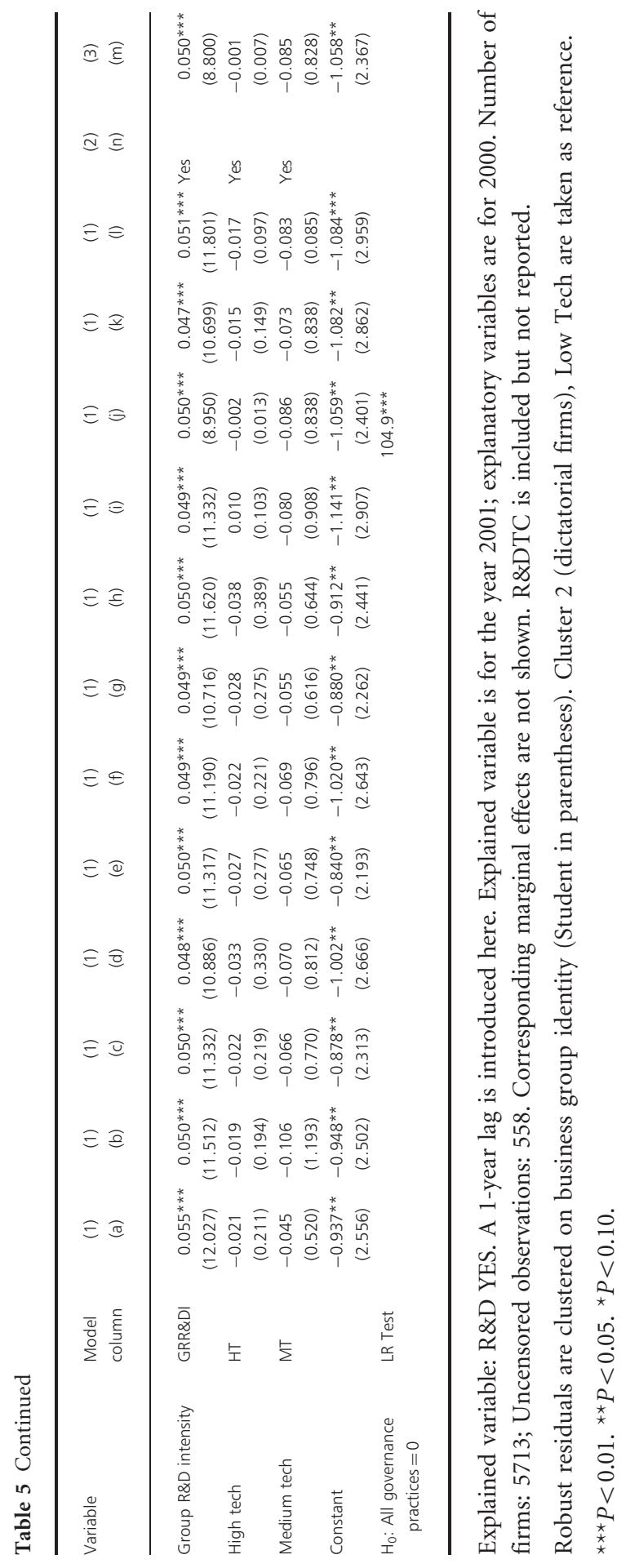




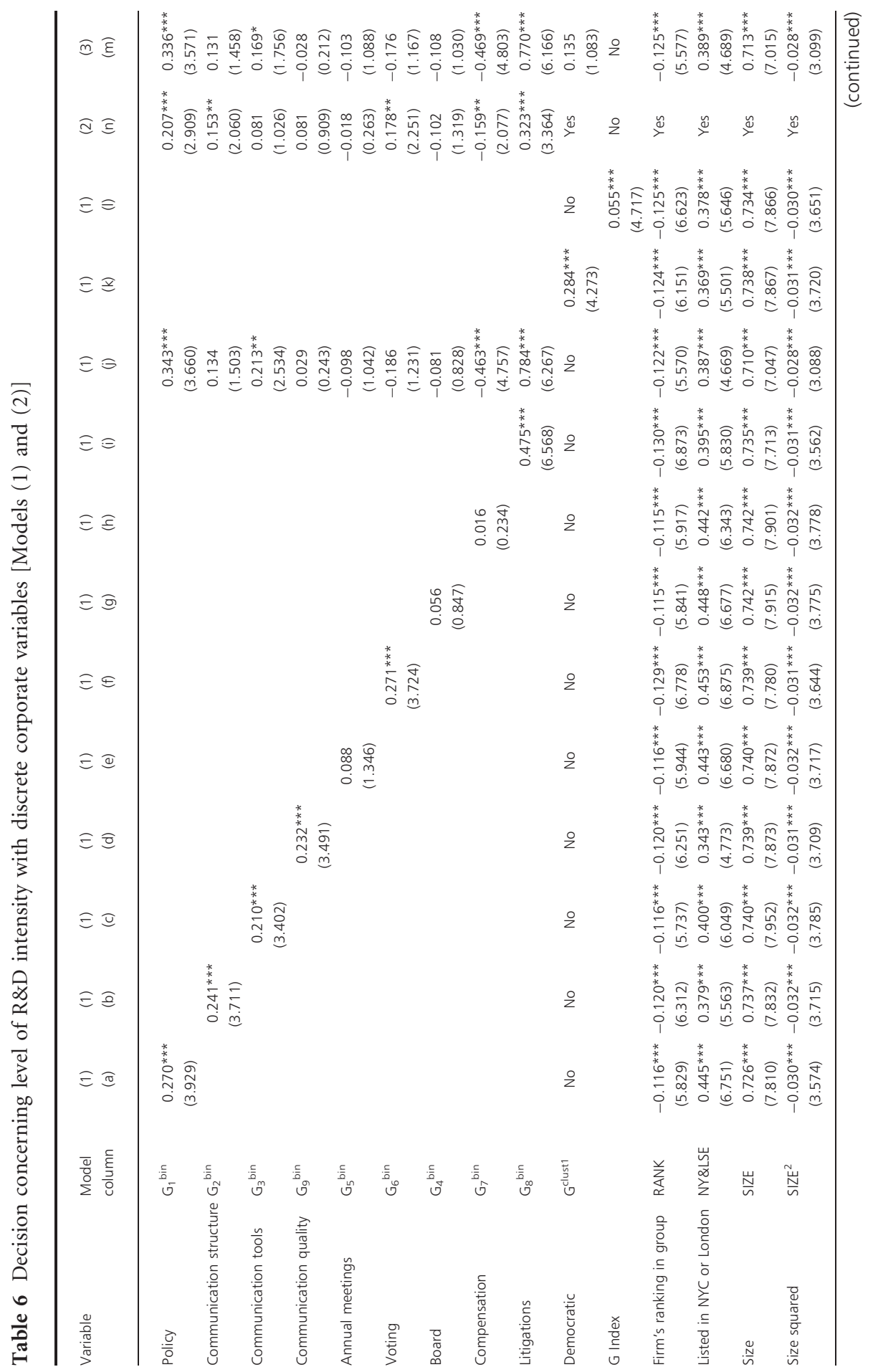




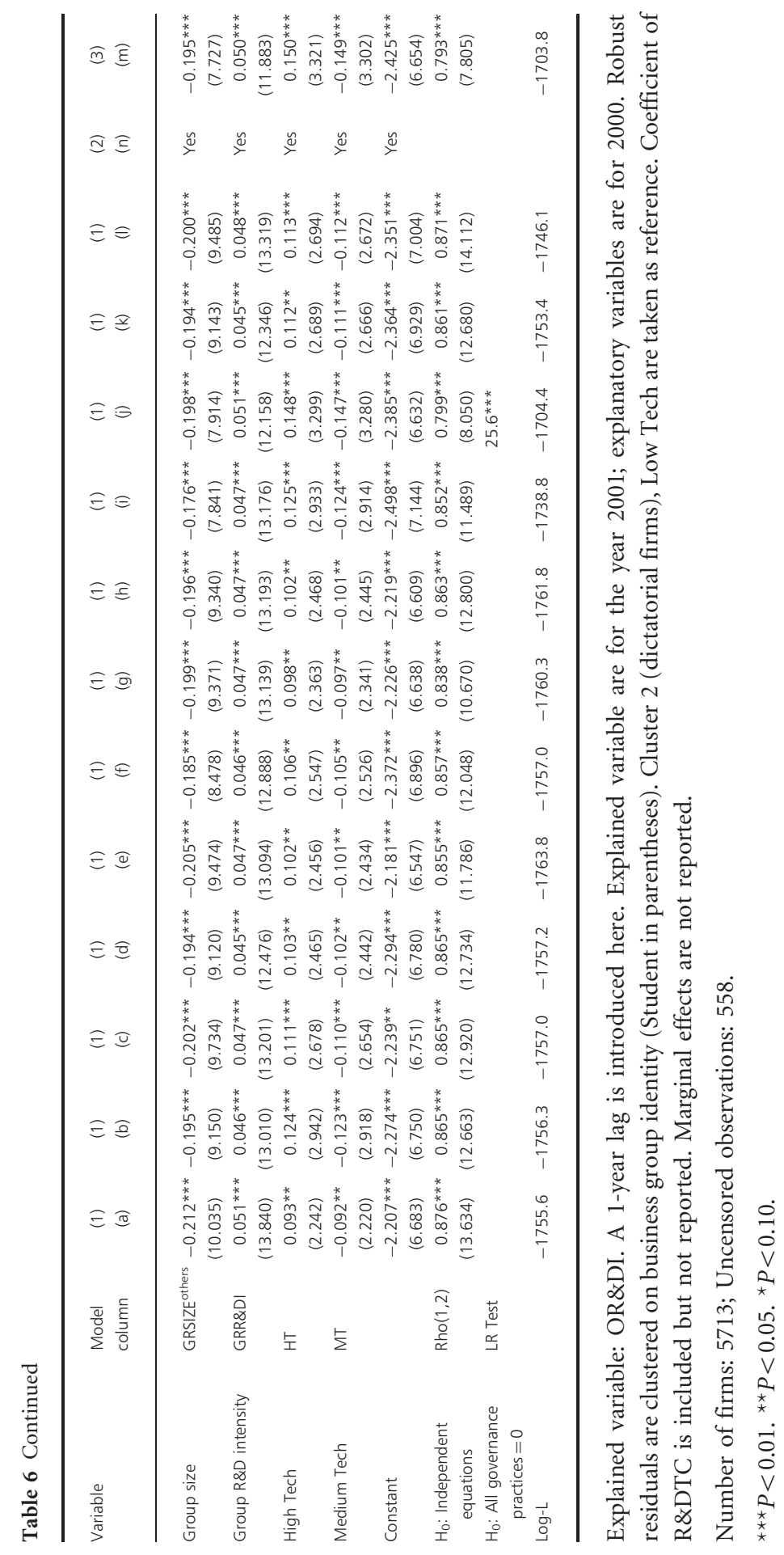


are in line with previous results on firm value obtained using governance indexes (e.g. Gompers, 2003).

When complementarity is explored, the following results are found: first, comparing the significance of parameters in columns $(\mathrm{a}-\mathrm{i})$ in Table 5 with the significance of individual parameters reported in column $(\mathrm{m})$ which include the Democratic dummy, six out of nine parameters become nonsignificant. If complementarity between practices holds, the Democratic cluster should explain the main part of the model and marginal changes in practices should not be significant anymore. This weak complementarity effect is found to be even weaker when the R\&D intensity equation is considered [column $(\mathrm{m})$ in Table 6] since only three parameters become nonsignificant. Second, as shown in column (n) in Tables 5 and 6, the Democratic dummy is not significantly different from zero when added to the whole set of governance practices. This last result also indicates that governance practices are not complementary. Consequently, our different econometric results provide little evidence for the existence of a complementarity effect among shareholder-oriented governance practices on $\mathrm{R} \& \mathrm{D}$ (i.e. H3 is rejected).

Firms belonging to business groups listed on the London or New York Stock Exchanges are more likely to be both $\mathrm{R} \& \mathrm{D}$ active and intensive. This suggests that there is significant influence from "Anglo-American" governance systems, something already advocated by some scholars (H4). However, the H4 hypothesis does not hold when the endogeneity of the NY\&LSE is controlled for (see Appendix A).

As all the columns in Tables 5 and 6 show the ranking of firms is found, as expected, to be negatively related to their $R \& D$ activities and intensity. This result verifies the hypothesis (H5) that a dilution effect of shareholders' rights and power along the control pyramid does in fact exist. The mainland European use of a control pyramid is thus to be considered as an efficient entrenchment strategy for French listed firms.

Concerning other control variables, larger firms are more likely to be involved in $\mathrm{R} \& \mathrm{D}$ activities and are also more $\mathrm{R} \& \mathrm{D}$ intensive but this positive influence decreases with increasing firm size. The R\&D intensity of sister and parent firms positively stimulates $R \& D$ investment of firms, underlining the complementarity of $R \& D$ activities within a business group. However, the larger the size of its sister firms, the less likely a firm is to be involved in R\&D and the less intensive its commitment to $\mathrm{R} \& \mathrm{D}$.

Finally, a selection effect was found to be significant for our SBF120 firms but the bias was not large enough to modify our results (see Appendix A).

\section{Conclusion}

The present article proposes an original approach to the investigation of the influence of corporate governance on $\mathrm{R} \& \mathrm{D}$ decisions based on governance practices. 
We introduced a distinction between the positive, additive, and complementarity effects which various identified shareholder-oriented practices may have on R\&D decisions. The existence of complementarity is shown to be of critical importance both in properly interpreting the existence of positive and additive effects, as for example, when identifying and characterizing the existing systems of corporate governance. We further proposed to control for two practices implemented by mainland European firms and usually overlooked: the place of firms in the control pyramid created by business groups and their choice to be cross-listed on the New York City or London Stock markets.

Based on a sample of 5528 firms belonging to the 110 largest French listed firms, our results on individual practices $(\mathrm{H} 1)$ validate the hypothesis that pro-shareholder governance practices have a positive influence on $\mathrm{R} \& \mathrm{D}$ investments. These results are in line with other previous results and apparently confirm agency theory views. Even if the impact of cross-listing ( $\mathrm{H} 4)$ is found to be insignificant, the proximity to the ultimate owner in a control pyramid (H5) is found to be beneficial for R\&D investment, reinforcing the standard idea that entrenchment practices are harmful to R\&D. Furthermore, the introduction of any additional shareholder-oriented practice is associated with more R\&D activity or investment (H2 is supported), and substantiates the idea that complex control requires multiple incentives. Our results suggest, however, that two governance practices which are core to the shareholder modelcompensation schemes and voting rules, do not influence R\&D intensity. A more systemic view further confirms the existence of several corporate governance models cohabiting in France and particularly identifies a shareholder-oriented model of governance where only some practices are implemented. When the model is carefully scrutinized, however, complementarity among its constitutive governance practices is not verified (i.e. H3 is not supported).

Table 7 recapitulates our main results.

The tested complementarity hypothesis (H3) has major implications for the analysis of corporate governance. First, if we had not explored H3, doubt would have

Table 7 Summary of our main results

\begin{tabular}{|c|c|c|c|c|c|}
\hline \multirow[t]{2}{*}{ Effects } & $\mathrm{H} 1$ & $\mathrm{H} 2$ & H3 & \multirow{3}{*}{$\begin{array}{l}\mathrm{H} 4 \\
\text { Cross-listing has } \\
\text { a positive effect }\end{array}$} & \multirow{3}{*}{$\begin{array}{l}\text { H5 } \\
\text { Control pyramid } \\
\text { has a negative effect }\end{array}$} \\
\hline & \multicolumn{3}{|c|}{ Shareholders' rights are positive and: } & & \\
\hline on: & Significant & Additive & Complementary & & \\
\hline R\&D or not & Often & Yes & No & No & Yes \\
\hline R\&D intensity & Often & Yes & No & No & Yes \\
\hline
\end{tabular}


lingered regarding the lack of impact on R\&D of certain single practices [e.g. compensation schemes (H1d), board practices (H1c) or communication at the general assembly (H1b)]. The rejection of the complementarity hypothesis is the only means to prove that, in France, these latter three practices do not in fact significantly influence certain $\mathrm{R} \& \mathrm{D}$ decisions. Considering that these hypotheses are central to the shareholder model, our results cast doubt on the general relevance of the pure shareholder model in the French context. Second, the complementarity hypothesis enables us to substantiate the doubts regarding the "Anglo-Americanization" of mainland European firms. Using an approximate bipolar view contrasting the Anglo-Saxon model with the elite coordinated French one, our results highlight the adoption, by many listed French firms, of intermediate corporate governance models which increase R\&D. From the lack of complementarity among shareholders' rights implemented by these firms, our results suggest that the French hybrid governance model we have identified here lacks viability since it is not likely, when its components are adopted together, to bring some additional performance regarding R\&D investments. We suggest from this result that the hybrid model we have identified has evolved during the recent years even if this model does not seem to have yet converged toward an efficient and stable model, particularly that of the Anglo-American archetype.

There are several contributions to the literature on the organization of innovation in this article. The first is to show that routines and organizational practices are not restricted to HRM practices and can be extended to corporate governance aspects. Our analysis proposes a means to reinvigorate the origin and the role of incentives and rewards in firms investing in $\mathrm{R} \& \mathrm{D}$ activities. More particularly, our work suggests that incentives are to be considered not only at the R\&D employee level but at all levels-from R\&D employees up to top managers. Our analysis also shows that beyond incentive schemes, governance practices shape information systems and are therefore an important aspect likely to influence the way decisions are observed and monitored by shareholders or other stakeholders. Doing so, problem solving activities or searching activities are likely to be influenced by the different administration practices for employees even if we agree that some organizational practices can be implemented by managers in a purely symbolic way. Our article also provides evidence that the influence of governance practices on R\&D decisions goes beyond the firm level to encompass all the bodies belonging to the same business group. This result supports some recent efforts carried out on the role of business groups on $\mathrm{R} \& \mathrm{D}$ and innovation activities and performances (Chang et al., 2006; Belenzon and Berkovitz, 2010; Vissa et al., 2010).

The present article is a first step toward integrating corporate governance practices into the analysis of innovation. $\mathrm{R} \& \mathrm{D}$, on which the present article is focused may, however, be a poor indicator for innovative efforts. IBM or ATT are famous examples of firms unable to transform their large $\mathrm{R} \& \mathrm{D}$ efforts into innovations. Several interpretations based on the weakness of governance models can explain 
this gap between $R \& D$ and innovation. For example, business firms may subcontract out R\&D in order to transfer risks to R\&D suppliers (as in Francis and Smith, 1995). Similarly, managers may spend a lot of money on R\&D but distribute risks in several small and superficial R\&D projects. Many R\&D projects can even be initiated by managers without any subsequent innovation (Greve, 2003). Hence, R\&D expenditures do not necessarily reflect the risks really taken by managers. A joint analysis of $\mathrm{R} \& \mathrm{D}$ and innovation would, therefore, seem a natural next step in order to understand the real role of corporate governance in these respects.

Our article also shares certain aspects of neo-institutionalist study on firms. We contend that macro-institutions are likely to influence the organizational practices implemented within a firm or a business group. In particular, the lack of results we obtained on incentives suggests that social, legal, and/or fiscal rules can neutralize organizational practices that would be effective in another institutional context or country. We interpret the lack of impact of Anglo-American incentive schemes (mainly stock options) in France as the failure of such a general tool to create employees' alignment, since the commitment of employees relies on other individual and collective rewards in France. This result complements recent results investigating the role of intrinsic and extrinsic motivations on innovation (see Sauermann and Cohen, 2008). A further contribution suggested by our model, even if our results here are disappointing, is that globalized firms can take advantage of the differences between national specific institutions in order to introduce new practices.

These aspects led us to generalize the idea that governance practices influencing strategic decisions such as R\&D or innovation are likely to experience some hybridization processes where certain practices replace or supplement others and are adapted from other corporate governance models. We explored the restricted role of the Anglo-American stakeholder model on the transformation of the French corporate governance model for large public firms, but we acknowledge that a more general hybridization process can occur between different governance models co-existing in France. The restricted number of firms in our sample prevents us from producing a more precise taxonomy and more precise results. We also concede that additional institutional layers (e.g. financial system, labor market), which we do not consider in this article are likely to influence governance practices (see Aoki and Jackson, 2008) and thus R\&D and innovation.

For example, we explore the impact of governance practices on $R \& D$ without considering explicitly the role of government, and particularly the role of S\&T policies. This is obviously a missing dimension since France is a leading country in terms of public support to civil business R\&D expenditures (see OECD, 2008). In our framework, it can be argued that French governments are used to support the risks that large entrenched firms are usually not willing to take. A further interpretation is that these firms obtain access to important public research organizations' results, $R \& D$ subsidies and $R \& D$ tax credits among other types of assistance as soon as they agree to limit lay-offs or job delocalization. Our results on the impact of the 
hybridization process suggest that S\&T policy makers should adapt their tools to the different coexisting corporate governance models. The rising share of the generic $\mathrm{R} \& \mathrm{D}$ tax credit against $\mathrm{R} \& \mathrm{D}$ subsidies over the last 25 years suggests however that S\&T policy makers and firms are more likely to preserve the historical pact in order to maintain employment whatever the trajectories of national corporate governance models become. One problem is that this type of dominant institutional arrangement seems inefficient compared with other national institutional systems, as attested to by the persistent lack of innovation, high-tech entrepreneurship, competitiveness and growth seen in France over the last 30 years.

Regarding the neo-institutionalist literature, our contribution can also be considered from the empirical methodology point of view: The neo-institutionalist literature emphasizes that firms articulate in a complementary way different management practices with heterogeneous and specific (national) institutional rules in order to achieve better performances (Aoki, 2001; Hall and Soskice, 2001). This literature provides interesting taxonomies at the national level (Amable, 2003) or at the firm level (Aoki and Jackson, 2008) but despite some empirical efforts carried out in order to test complementarity (see Hall and Gingerich, 2004; Kenworthy, 2006), it fails to provide empirical substantiation of the claimed complementarity of adopted governance practices and/or institutions. Instead, the empirical method we apply, borrowed from Ichniowsky et al. (1997), allows us to go one step further in order to test whether the identified corporate models or clusters of practices are likely to be stable ideal types (if the complementarity does exist) or likely to evolve toward another organizational type (if no complementarity exists). We think that this statistical method is all the more relevant as it is flexible enough to include additional layers of institutional practices in order to get a bigger picture of the complementarity and the stability of institutionalized models of either firms or higher level units of analysis (sectors, countries).

\section{Acknowledgements}

We would like to thank the following: Vigeo for providing us with their data as well as explanations and comments on their methodology. The Ministry of Industry (SESSI) and the Ministry of Research and Higher Education (Statistical office and R\&D tax credit office) for providing their data. Christiano Antonelli, Fouad Benseddik, Christian Le Bas, Luis Miotti, Mouhoub El Mouhoud, Pierre-Jean Mouniq, Morris Teubal, Chris Tucci, and the participants at the 2006 Lisbon DIME Workshop, "Motivations and Incentives: Creating and Sharing Knowledge in Organizational Contexts," the participants at the 2006 Swiss Society of Economics and Statistics annual meeting on Industrial Organization, Innovation and Regulation in Lugano, the two referees and finally the editor for their helpful comments. The usual disclaimer applies. 


\section{References}

Agrawal, A. and C. R. Knoeber (1996), 'Company performance and mechanisms to control agency problems between managers and shareholders,' The Journal of Financial and Quantitative Analysis, 31(3), 377-397.

Aguilera, R. V., I. Filatotchev, H. Gospel and G. Jackson (2008), 'An organizational approach to comparative corporate governance: Costs, contingencies, and complementarities,' Organization Science, 19, 475-492.

Amable, B. (2003), 'The Diversity of Modern Capitalism'. Oxford University Press: New York, USA.

Aoki, M. (2001), Toward a Comparative Institutional Analysis. MIT Press: Cambridge, USA.

Aoki, M. (2007), 'Whither Japan's Corporate Governance?,' in M. Aoki, G. Jackson and H. Miyajima (eds), Corporate Governance in Japan: Institutional Change and Organizational Diversity. Oxford University Press: New York, USA, pp. 427-459.

Aoki, M. and G. Jackson (2008), 'Understanding an emergent diversity of corporate governance and organizational architecture: An essentiality-based analysis,' Industrial and Corporate Change, 17, 1-27.

Barker, V. L. and G. C. Mueller (2002), 'CEO characteristics and Company Spending,' Management Science, 48(6), 82-801.

Bebchuk, L., J. C. Coates IV and G. Subramanian (2002), 'The Powerful Antitakeover Force of Staggered Boards: Theory, Evidence and Policy,' NBER Working Papers 8974. National Bureau of Economic Research, Inc.

Bebchuk, L., A. Cohen and A. Ferrell (2009), 'What matters in corporate governance?' Review of Financial Studies, 22(2), 783-827.

Belenzon, S. and T. Berkovitz (2010), 'Innovation in business groups,' Management Science, 56(3), 519-535.

Berry, T. K., L. P. Fields and M. S. Wilkins (2006), 'The interaction among multiple governance mechanisms in young newly public companies,' Journal of Corporate Finance, 12, $449-466$.

Blass, A. and Y. Yafeh (2001), 'Vagabond shoes longing to stray: Why foreign firms list in the United States,' Journal of Banking \& Finance, 25(3), 555-572.

Blass, A. A. and O. Yosha (2003), 'Financing R\&D in mature companies: an empirical analysis,' Economics of Innovation and New Technologies, 12(5), 425-447.

Boone, A. L., L. C. Field, J. M. Karpoff and C. G. Raheja (2007), 'The determinants of corporate board size and composition: An empirical analysis,' Journal of Financial Economics, 85(1), 66-101.

Cassiman, B. and R. Veugelers (2002), 'R\&D cooperation and spillovers: some empirical evidence from Belgium,' American Economic Review, 92(4), 1169-1184.

Cescon, F. (2002), 'Short-term perceptions. Corporate governance and the management of R\&D in Italian companies,' Journal of Management and Governance, 6(3), 255-270. 
Chambers, D., R. Jennings and R. B. Thompson II (2003), 'Managerial discretion and accounting for research and development,' Journal of Accounting, Auditing \& Finance, 18(1), 79-113.

Chang, S. J., C. N. Chung and I. P. Mahmood (2006), 'When and how does business group affiliation promote firm innovation? A tale of two emerging economies,' Organization Science, 17(5), 637-656.

Cho, S. (1992), 'Agency costs, management stockholding, and research and development expenditures,' Seoul Journal of Economics, 5(2), 127-52.

Claessens, S., S. Djankov and L. H. P. Lang (2000), 'The separation of qwnership and control in East Asian corporations,' Journal of Financial Economics, 58, 81-112.

Cockburn, I. M., R. M. Henderson and S. Stern (2000), 'Untangling the origins of competitive advantage,' Strategic Management Journal, 21(10-11), 1123-1145.

Cohen, W. M. and D. A. Levinthal (1990), 'Absorptive capacity: A new perspective on learning and innovation,' Administrative Science Quarterly, 35(1), 128-152.

Cremers, K. J. M. and V. Nairs (2005), 'Governance mechanisms and equity prices,' Journal of Finance, 60(6), 2859-2894.

Czarnitzki, D. and K. Kraft (2003), 'Management control and innovative activity,' Review of Industrial Organisation, 24(1), 1-24.

Danielson, M. G. and J. M. Karpoff (1998), 'On the uses of corporate governance provisions,' Journal of Corporate Finance, 4(4), 347-371.

Danielson, M. G. and J. M. Karpoff (2006), 'Do pills poison operating performance?' Journal of Corporate Finance, 12, 536-559.

Dares (2004), 'Participation, intéressement, plans d'épargne : plus d'un salarié sur deux est concerné fin 2002,' Premières Synthèses, n ${ }^{\circ} 38.1$, Ministère de l'emploi, du travail et de la cohésion sociale, Direction de l'animation de la recherche des études et des statistiques (DARES).

Doidge, C., A. Karolyi and R. Stultz (2004), 'Why are foreign companies listed in the U.S. worth more?' Journal of Financial Economics, 71(2), 205-238.

Doidge, C., A. Karolyi and R. Stulz (2007), 'Has New York Become Less Competitive in Global Markets? Evaluating Foreign Listing Choices Over Time,' NBER Working Papers 13079 .

Dosi, G. (1988), 'Sources, procedures, and microeconomic effects of innovation,' Journal of Economic Literature, 26(3), 1120-1171.

Dosi, G., D. A. Levinthal and L. Marengo (2003), 'Bridging contested terrain: Linking incentive-based and learning perspectives on organizational evolution,' Industrial and Corporate Change, 12(2), 413-436.

Eng, L. L. and M. Shackell (2001), 'The implications of long term performance plans and institutional ownership for companies' research and development investments,' Journal of Accounting, Auditing and Finance, 16(2), 117-39. 
Faccio, M. and L. H. P. Lang (2002), 'The ultimate ownership of western European corporations,' Journal of Financial Economics, 65(3), 365-395.

Fama, E. F. and M. C. Jensen (1983), 'Separation of ownership and control,' Journal of Law and Economics, 26, 301-325.

Fiss, P. C. and E. J. Zajac (2004), 'The diffusion of ideas over contested terrain: The (non) adoption of a shareholder value orientation among German firms,' Administrative Science Quarterly, 49(4), 501-534.

Foss, N. J. (2007), 'The Emerging Knowledge Governance: Challenges and Characteristics,' Organization, 14(1), 29-45.

Francis, J. and A. Smith (1995), 'Agency costs and innovation: Some empirical evidence,' Journal of Accounting and Economics, 19(2-3), 383-409.

Gompers, P. A., J. L. Ishii and A. Metrick (2003), 'Corporate governance and equity prices,' Quarterly Journal of Economics, 118(1), 107-155.

Goyer, M. (2003), 'The Transformation of Corporate Governance in France,' US-France Analysis series, January 7. http://www.brookings.edu/ /media/Files/rc/articles/2003/01france_goyer/goyer.pdf (last accessed 7 January 2003).

Goyer, M. (2007), 'Capital mobility, varieties of institutional investors, and the transforming stability of corporate Governance in France and Germany,' in B. Hancké, M. Rhodes and M. Thatcher (eds), Beyond Varieties of Capitalism. Oxford University Press: New York, USA, pp. 195-219.

Grabowski, H. G. and D. C. Mueller (1978), 'Industrial research and development, intangible capital stocks, and firm profit rates,' The Bell Journal of Economics, 9(2), 328-343.

Greve, H. R. (2003), 'A behavioral theory of R\&D expenditures and innovations: Evidence from shipbuilding,' The Academy of Management Journal, 46(6), 685-702.

Gugler, K. (2003), 'Corporate governance, dividend payout policy, and the interrelation between dividends, R\&D, and capital investment,' Journal of Banking \& Finance, 27(7), 1297-1321.

Hall, P. A. and D. Soskice (2001), 'An introduction to varieties of Capitalism,' in P. Hall and D. Soskice (eds), Varieties of Capitalism: The Institutional Foundations of Comparative Advantage. Oxford University Press: New York, pp. 1-70.

Hall, P. A. and D. W. Gingerich (2004), 'Varieties of capitalism and institutional complementarities in the macroeconomy: an empirical analysis,' MPIfG Discussion Paper $04 / 5$.

Hanel, P. and A. St-Pierre (2002), 'Effects of R \& D spillovers on the profitability of firms,' Review of Industrial Organization, 20(4), 305-322.

Hermalin, B. E. and M. S. Weisbach (1998), 'Endogenously chosen boards of directors and their monitoring of the CEO,' American Economic Review, 88(1), 96-118.

Hirschey, M. (1982), 'Intangible capital aspects of advertising and R \& D expenditures,' Journal of Industrial Economics, 30, 375-389. 
Hitt, M. A., R. E. Hoskisson, R. A. Johnson and D. D. Moesel (1996), 'The market for corporate control and company innovation,' Academy of Management Journal, 39(6), 1084-1119.

Holmstrom, B. (1989), 'Agency costs and innovation,' Journal of Economic Behaviour and Organization, 12(3), 305-327.

Holthausen, R. W., D. F. Larcker and R. G. Sloan (1995), 'Business unit innovation and the structure of executive compensation,' Journal of Accounting and Economics, 19(2-3), 279-313.

Höpner, M. (2005), 'What connects industrial relations and corporate governance? Explaining institutional complementarity,' Socio-economic Review, 3(2), 331-358.

Hoskisson, R. E., M. A. Hitt and C. W. L. Hill (1993), 'Managerial incentives and investment in R\&D in large multiproduct companies,' Organization Science, 4(2), 325-341.

Hoskisson, R. E., M. A. Hitt, R. A. Johnson and W. Grossman (2002), 'Conflicting voices: The effects of ownership heterogeneity and internal governance on corporate strategy,' Academy of Management Journal, 45(4), 697-716.

Huimin, C. and Y. T. Mak (2002), 'The relationship between managerial ownership and company performance in high R\&D companies,' Journal of Corporate Finance, 8(4), 313-336.

Ichniowski, C., K. Shaw and G. Prennushi (1997), 'The effects of human resource management practices on productivity: A study of steel finishing lines,' The American Economic Review, 87(3), 291-313.

Johnson, M. S. and R. P. Rao (1997), 'The impact of antitakeover amendments on corporate financial performance,' The Financial Review, 32(3), 659-690.

Karolyi, G. A. (2006), 'The world of cross-listings and cross-listings of the world: Challenging conventional wisdom,' Review of Finance, 10(1), 1-54.

Kenworthy, L. (2006), 'Institutional coherence and macroeconomic performance,' SocioEconomic Review, 4(1), 69-91.

Khanna, T., J. Kogan and K. Palepu (2006), 'Globalization and similarities in corporate governance: A cross-country analysis,' Review of Economics and Statistics, 88(1), 69-90.

Khanna, T., K. G. Palepu and S. Srinivasan (2004), 'Disclosure practices of foreign companies interacting with U.S. markets,' Journal of Accounting Research, 42(2), 475-508.

Kleinknecht, A., T. P. Poot and J. O. N. Reijnen (1991), 'Formal and informal R\&D and company size,' in Z.J. Acs and D.B. Audretsch (eds), Innovation and Technological Change, An International Comparison. The University of Michigan Press: Ann Arbor, pp. $84-108$.

Kramarz, F. and D. Thesmar (2006), 'Social networks in the boardroom,' CEPR Discussion Papers 5496, C.E.P.R. Discussion Papers.

La Porta, R., F. Lopez-de-Silanes, A. Schleifer and R. W. Vishny (1999), 'Corporate ownership around the world,' Journal of Finance, 54(2), 471-517. 
La Porta, R., F. Lopez-de-Silanes, A. Schleifer and R. W. Vishny (1998), 'Law and Finance,' Journal of Political Economy, 106(6), 1113-1155.

Lacetera, N. (2001), 'Corporate governance and the governance of innovation: The case of pharmaceutical industry,' Journal of Management and Governance, 5(1), 29-59.

Levin, R. C., A. Klevorick, R. R. Nelson and S. G. Winter (1987), 'Appropriating the returns from industrial research and development,' Brookings Papers on Economic Activity, 1987(3), 783-831.

Mahoney, J. M., C. Sundaramurthy and J. T. Mahoney (1997), 'The effects of corporate antitakeover provisions on long-term investment: Empirical evidence,' Managerial and Decision Economics, 18(5), 349-365.

Mansfield, E., J. Rapoport, A. Romeo, S. Wagner and G. Beardsley (1977), 'Social and private rates of return from industrial innovations,' The Quarterly Journal of Economics, 91(2), 221-240.

Meulbroek, L. K., M. L. Mitchell, H. Mulherin, J. Netter and A. Poulsen (1990), 'Shark repellents and managerial myopia: An empirical test,' Journal of Political Economy, 98(5), 1108-1117.

Milgrom, P. and J. Roberts (1990), 'The economics of modern manufacturing: Technology, strategy, and organization,' The American Economic Review, 80(3), 511-528.

Mizruchi, M. S. (1996), 'What do interlocks do: An analysis, critique, and assessment of research on interlocking directorates,' Annual Review of Sociology, 22, 271-298.

Morck, R., D. Wolfenzon and B. Yeung (2005), 'Corporate governance, economic entrenchment and growth,' Journal of Economic Literature, 43(3), 655-720.

Moulton, B. R. (1986), 'Random group effects and the precision of regression estimates,' Journal of Econometrics, 32(3), 385-397.

Nelson, J. (2005), 'Corporate Governance practices, CEO characteristics and company performance,' Journal of Corporate Finance, 11, 197-228.

Nelson, K. and R. Nelson (2002), 'On the nature and evolution of human know-how,' Research Policy, 31, 719-733.

O’Reilly, C. A. and B. G. M. Main (2010), 'Economic and psychological perspectives on CEO compensation: a review and synthesis,' Industrial and Corporate Change 2010, 19(3), 675-712.

OECD (2008), Main Science and Technology Indicators (MSTI): 2008. 2nd edn. OECD: Paris.

OECD (Hatzichronoglou, T.) (1997), 'Revision of the High-Technology Sector and Product Classification', Working paper/DSTI, OECD: Paris.

Paris Stock Exchange (1996), 'The Paris Bourse Indices - Methodology and Supervision'. Association of French Stock Exchanges and Paris Stock Exchange: Paris.

Prendergast, C. (1999), 'The provision of incentives in firms,' Journal of Economic Literature, 37(1), 7-63. 
Pugh, W. N., D. E. Page and J. S. Jahera Jr (1992), 'Antitakeover charter amendments: Effects on corporate decisions,' Journal of Financial Research, 15(1), 57-68.

Ravenscarft, D. and F. M. Scherer (1982), 'The lag structure of return to research and development,' Applied Economics, 14, 603-620.

Ryan, H. and R. A. Wiggins (2002), 'The Interactions between R\&D Investment Decisions and Compensation Policy,' Financial Management, 31(1), 5-29.

Sarkissian, S. and M. J. Schill (2004), 'The overseas listing decision: New evidence of proximity preference,' Review of Financial Studies, 17(3), 769-809.

Sauermann, H. and W. M. Cohen (2008), 'What makes them tick? Employee Motives and Firm Innovation,' NBER Working Paper \#14443.

Spencer, Stuart (2005), Spencer Stuart 2005 Board Index. Spencer Stuart edn. p. 49.

Stein, J. (1988), 'Takeover threats and managerial myopia,' Journal of Political Economy, 96, 61-80.

Topkis, D. M. (1998), Supermodularity and Complementarity. Princeton University Press: Princeton, USA.

Tribo, J. A., P. Berrone and J. Surroca (2007), 'Do the type and number of blockholders influence R\&D investments? New evidence from Spain,' Corporate Governance: An International Review, 15(5), 828-842.

Tylecote, A. and P. Ramirez (2006), 'Corporate governance and innovation: The UK compared with the US and 'insider” economies,' Research Policy, 35(1), 160-180.

Vissa, B., H. R. Greve and W. R. Chen (2010), 'Business group affiliation and firm search behavior in India: Responsiveness and focus of attention,' Organization Science, 21(3), 696-712.

Westphal, J. D. and E. J. Zajac (1998), 'The symbolic management of stockholders: corporate governance reforms and shareholder reactions,' Administrative Science Quarterly, 43(1), 127-153.

Williamson, O. E. (1975), Markets and Hierarchies: Analysis and Antitrust Implications. The Free Press: New York.

Xue, Y. (2007), 'Make or buy new tech. - A CEO compensation contract's role in a company's route to innovation,' Review of Accounting Studies, 12(4), 659-690.

Yafeh, Y. and O. Yosha (2003), 'Large shareholders and banks: who monitors and how?' The Economic Journal, 113(484), 128-146.

Zahra, S. A., D. O. Neubaum and M. Huse (2000), 'Entrepreneurship in medium-size companies: Exploring the effects of ownership and governance systems,' Journal of Management, 26(5), 947-976. 


\section{Appendix A}

\section{Econometric issues and robustness checks}

Several difficulties are encountered in our estimations when consistent coefficients and appropriate standard errors are to be identified. First, due to the introduction of variables at the business group level in our model, not all regressors vary along all dimensions. Disturbances may be correlated within business groups (Moulton, 1986). While coefficients would still be unbiased, standard errors could be downward biased. To overcome this problem, we cluster the residuals on business group identity. A second standard problem in corporate governance literature is the causality between governance variables and R\&D (Francis and Smith, 1995; Hermalin and Weisbach, 1998). We expect a positive impact of shareholder-oriented governance practices on $\mathrm{R} \& \mathrm{D}$ whereas $\mathrm{R} \& \mathrm{D}$ may also create different governance entrenchment procedures. In order to mitigate this causality problem, a 1-year lag is introduced in all our empirical models.

Two additional problems deserve attention. The first is the possible endogeneity of the NYSE variable. We consider that the SBF120 business groups with affiliates belonging to concentrated markets are dominant and more likely to choose an Anglo-Saxon stock market. ${ }^{12}$ Our first equation thus includes as an explanatory variable the 2000 Herfindhal index (HHI) computed at the two-digit level:

$$
\text { NY\&LSE } E_{i t}=H\left(\text { Democratic }_{\text {gt }}, \mathrm{HHI}_{\mathrm{it}}, \mathrm{RANK}_{\mathrm{it}} \text {, Control }_{\mathrm{it}}\right)
$$

where the linear predicted value is introduced in our fourth $\mathrm{R} \& \mathrm{D}$ model:

$$
\mathrm{R} \& \mathrm{D} \mathrm{YES}_{\mathrm{it}+1}=\mathrm{K}\left(\mathrm{NY} \& \mathrm{LSE}_{\mathrm{it}}^{\mathrm{pred}}, \mathrm{RANK}_{\mathrm{it}}, \text { Control1 }_{\mathrm{it}}\right)
$$

A second similar model explores the impact of practices on $R \& D$ intensity. In order to join $R \& D$ firms with non-R\&D firms, we need to define a new explained variable OR\&D that is the combination of R\&DYES and OR\&DI. OR\&D is a five-scale variable where $O R \& D=0$ if $R \& D$ YES $=0, O R \& D=1$ if $O R \& D I=1,2$ if $\mathrm{OR} \& \mathrm{DI}=2,3$ if $\mathrm{OR} \& \mathrm{DI}=3$, and 4 if $\mathrm{OR} \& \mathrm{DI}=4$. We thus estimate the ordered model using, as in equation (4), the predicted value for the NY\&LSE variable:

$$
\mathrm{OR} \& \mathrm{D}_{\mathrm{it}+1}=\mathrm{M}\left(\mathrm{NY} \& \mathrm{LSE}_{\mathrm{it}}^{\mathrm{pred}}, \mathrm{RANK}_{\mathrm{it}}, \text { Control1 }_{\mathrm{it}}\right)
$$

Results reported in Table A1 show that the appropriate standard errors are lower than in Model (1). The $t$-student values decrease from 2.27 (Column $\mathrm{k}$ in Table 5) to 1.296 [Model (3) in Table A1]. Model (5) in Table A1 also suggests that cross-listing

\footnotetext{
${ }^{12} \mathrm{~A}$ second instrument could be exports (see Doidge et al., 2004; Sarkissian and Schill, 2004). However, this is correlated in this study with the residuals in the R\&D equation. This is not the case for concentration, which is not correlated with R\&D investment decisions or intensity.
} 
Table A1 Exploring endogeneity of NY\&LSE [Models (3) and (4)] and sample selection [Model (5)]

\begin{tabular}{|c|c|c|c|c|}
\hline Variable & $\begin{array}{l}\text { Model: } \\
\text { Explained } \\
\text { variables: }\end{array}$ & $\begin{array}{c}(4) \\
\text { RD YES }\end{array}$ & $\begin{array}{c}(5) \\
\text { OR\&D }\end{array}$ & $\begin{array}{c}(6) \\
\text { OR\&D }\end{array}$ \\
\hline Democratic & $\mathrm{G}^{\text {clust1 }}$ & $\begin{array}{l}0.331^{* *} \\
(2.065)\end{array}$ & $\begin{array}{l}0.298^{* *} \\
(2.204)\end{array}$ & $\begin{array}{l}0.210^{* * *} \\
(3.387)\end{array}$ \\
\hline Firm's ranking in group & RANK & $\begin{array}{l}-0.115^{* * *} \\
(3.301)\end{array}$ & $\begin{array}{l}-0.107^{* * *} \\
(3.271)\end{array}$ & $\begin{array}{l}-0.119^{* * *} \\
(5.950)\end{array}$ \\
\hline Listed in NYC or London & NY\&LSE & & & $\begin{array}{l}0.243^{* * *} \\
(4.119)\end{array}$ \\
\hline Listed in NYC or London & NY\&LSE ${ }^{\text {pred }}$ & $\begin{array}{c}0.412 \\
(1.296)\end{array}$ & $\begin{array}{l}0.373 \\
(1.215)\end{array}$ & \\
\hline Size & SIZE & $\begin{array}{l}0.728^{* * *} \\
(4.837)\end{array}$ & $\begin{array}{l}0.660 * * * \\
(5.207)\end{array}$ & $\begin{array}{l}0.540 * * * \\
(5.047)\end{array}$ \\
\hline Size squared & $\mathrm{SIZE}^{2}$ & $\begin{array}{l}-0.030^{* *} \\
(2.409)\end{array}$ & $\begin{array}{l}-0.027^{* * *} \\
(2.604)\end{array}$ & $\begin{array}{l}-0.019^{* *} \\
(2.111)\end{array}$ \\
\hline Group size & GRSIZE $^{\text {others }}$ & $\begin{array}{l}-0.193^{* * *} \\
(5.037)\end{array}$ & $\begin{array}{l}-0.165^{* * *} \\
(4.911)\end{array}$ & $\begin{array}{l}-0.317^{* * *} \\
(7.205)\end{array}$ \\
\hline Group R\&D intensity & GRR\&DI others & $\begin{array}{l}0.036^{* * *} \\
(6.026)\end{array}$ & $\begin{array}{l}0.035^{* * *} \\
(6.123)\end{array}$ & $\begin{array}{l}0.038^{* * *} \\
(9.500)\end{array}$ \\
\hline High Tech & HT & $\begin{array}{l}0.347^{*} \\
(2.372)\end{array}$ & $\begin{array}{l}0.316^{* *} \\
(2.364)\end{array}$ & \\
\hline Medium Tech & MT & $\begin{array}{r}-0.060 \\
(0.427)\end{array}$ & $\begin{array}{l}0.049 \\
(0.401)\end{array}$ & \\
\hline $\begin{array}{l}\text { Industry dummies (Nace2) } \\
\text { Constant }\end{array}$ & & $\begin{array}{c}\text { No } \\
-2.282^{* * *} \\
(5.048)\end{array}$ & No & Yes \\
\hline $\begin{array}{l}\text { Log pseudo likelihood } \\
\mathrm{H}_{0} \text { : All coefficient }=0\end{array}$ & & $\begin{array}{l}-1088.0 \\
457.5^{\star * *}\end{array}$ & $\begin{array}{l}-1845.3 \\
703.1 * * *\end{array}$ & -8543.5 \\
\hline Number of firms & & 5713 & 5713 & 41273 \\
\hline $\begin{array}{l}\text { Uncensored observations } \\
\text { Pseudo } R^{2}\end{array}$ & & & & 5713 \\
\hline Selection equation & & No & No & Yes \\
\hline $\begin{array}{l}\mathrm{H}_{0} \text { : Independent } \\
\quad \text { equations }(\rho=0)\end{array}$ & & & & $-0.44^{* * *}$ \\
\hline
\end{tabular}

Robust residuals are clustered on business group identity. Cluster 2 (dictatorial firms), Low Tech are taken as reference in all models. R\&DTC is included in all models but not reported. In Models (4) and (5), the auxiliary regression (not reported) gives NYSE ${ }^{\text {pred }}$. Marginal effects in Models (4) and (5) are not shown. In Models (5) and (6), the cut-off values are not reported. In Model (6), selection equations are not reported. In Model (6), the larger number of firms facilitates the introduction of industry dummies. At a two-digit level (not reported) instead of the HT, MT, LT dummies.

${ }^{* * *} P<0.01 .{ }^{* *} P<0.05 .{ }^{*} P<0.10$. 
is not a determinant for intensive $\mathrm{R} \& \mathrm{D}$ subsidiaries ( $t$-student value is now 1.215) and thus that the $\mathrm{H} 4$ hypothesis not longer holds.

A second potential bias leading to an inconsistent estimate of our coefficients in equation (1) may be due to the nonrandom selection of our sample focusing on the 120 largest French listed firms. We introduce a selection equation to Model (5) explaining the probability of being listed in the SBF120 French index (SBF120 = 1 instead of 0). The likelihood of being an SBF120 affiliate is explained by the size of the business group to which the firm belongs (GRSIZE) and the intensity of R\&D in this group (GRR\&DI). We also control for possible bias induced by the ranking of affiliates (RANK) and cross-listing (NY\&LSE) even though there was no French corporate firm listed abroad which was not also included in the SBF120 list. The final model is thus a new Heckman ordered probit model:

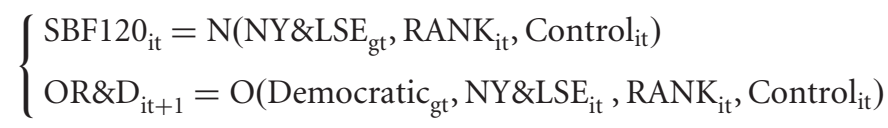

The correlation coefficient among residuals $(\rho)$ is found to be significantly different from $0(P<0.01)$ (see Table A1). This result is also a novel contribution to the literature as it shows that, without the analysis of the characteristics of the selected sample, the impact of governance practices on R\&D intensity may rely on the sole characteristics of the chosen sample. However, the corrected estimation for the coefficient of the Democratic dummy gives similar results to those in Model (5) [Table A1, Model (6) versus (5)]. 